STUDIA POLONIJNE

T. 37. Lublin 2016

DOI: http://dx.doi.org/10.18290/sp.2016.4

\title{
ODRODZENIE ŻYCIA RELIGIJNEGO W UKRAIŃSKIEJ SOCJALISTYCZNEJ REPUBLICE RADZIECKIEJ \\ W ŚWIETLE ARTYKUŁÓW ZAMIESZCZONYCH NA ŁAMACH ,TYGODNIKA POWSZECHNEGO” W LATACH 1988-1991
}

\author{
WSTĘP
}

Powojenne przesunięcie wschodniej granicy II Rzeczypospolitej spowodowało, że na terytorium Ukraińskiej Socjalistycznej Republiki Radzieckiej (jednej z szesnastu republik tworzących ZSRR) znalazło się około 400 parafii archidiecezji lwowskiej, 167 parafii diecezji łuckiej (w całości znalazła się w obrębie imperium sowieckiego) oraz 75 parafii diecezji przemyskiej, wchodzących w skład przedwojennej metropolii lwowskiej ${ }^{1}$. Jeszcze przed formalnym zakończeniem działań wojennych i wytyczeniem nowej granicy polsko-radzieckiej Sowieci, mający na tym polu już spore doświadczenia, przystąpili do niszczenia lokalnych struktur Kościoła katolickiego².

Mgr ŁuKASZ JONIEC - doktorant, Instytut Historii na Wydziale Socjologiczno-Historycznym Uniwersytetu Rzeszowskiego; e-mail: jonieclukasz@interia.eu

${ }^{1}$ R. DzwonkowsKI, Religia i Kościót katolicki w ZSRR oraz $w$ krajach i na ziemiach okupowanych 1917-1991; kronika, Lublin: TN KUL 2010, s. 437.

${ }^{2}$ Walka z religią katolicką wynikała nie tylko z podstawowych założeń ideologii sowieckiego systemu komunistycznego, ale także miała na celu doprowadzenie do depolonizacji ziem wchodzących przez stulecia w skład państwa polskiego. Wyznanie rzymskokatolickie pokrywało się bowiem na tych terenach zasadniczo z narodowością polską, a Kościół stał się w tym czasie jedynym bastionem polskości, dlatego też jego działalność, wyjęta spod nadzoru służb sowieckich, nie mogła być akceptowana przez Moskwę. Pod pojęciem katolików na Ukrainie będziemy rozumieć przede wszystkim osoby wyznania rzymskokatolickiego polskiego pochodzenia. Tam, gdzie będzie mowa o katolikach obrządku wschodniego, zostanie to wyraźnie zaznaczone. 
Większość świątyń zamieniono na magazyny, sale koncertowe, hotele robotnicze czy muzea ateizmu - te miały najwięcej szczęścia. Inne bowiem, jak np. neogotycki kościół parafialny w Tarnopolu, znikły z powierzchni ziemi, ustępując miejsca popularnym w tym czasie domom handlowym ${ }^{3}$. Życie religijne prawie zanikło $^{4}$. Świątynie katolickie oraz sami katolicy zamieszkujący zachodnie tereny ZSRR podzielili losy tych, którzy już wcześniej znaleźli się pod zwierzchnictwem władz radzieckich.

Stan ten, z niewielkimi tylko zmianami, trwał praktycznie do końca lat osiemdziesiątych, kiedy to na skutek wprowadzanych w ZSRR przez Michaiła Gorbaczowa reform, złagodzono politykę państwa także w kwestiach wiary. Bezpośrednią konsekwencją tych reform był zapoczątkowany wtedy proces odrodzenia religijnego. Wszędzie tam, gdzie przetrwało przywiązanie do religii, zawiązywano komitety kościelne i rozpoczynano starania o zwrot zamkniętych po wojnie kościołów ${ }^{5}$.

Niniejszy artykuł ma na celu omówienie, czy i w jakim stopniu informacje o odradzającym się za wschodnią granicą Polski życiu religijnym docierały do polskiego czytelnika. Przykładem będzie dla nas „Tygodnik Powszechny” („TP”), jeden z najbardziej opiniotwórczych tygodników ukazujących się wówczas w Polsce, docierający do szerokiego kręgu czytelników i wywołujący nierzadko gorące dyskusje ${ }^{6}$.

Niezbędne wydaje się jeszcze wyjaśnienie, dlaczego jego tematyka zamyka się w latach 1988-1991. Powodów jest kilka. Najważniejszym jest fakt, iż był to okres, kiedy katolikom udało się odzyskać najwięcej parafii rzymskokatolickich.

\footnotetext{
${ }^{3}$ R. Dzwonkowski, Religia i Kościót katolicki, s. 447.

${ }^{4} \mathrm{Na}$ terenie archidiecezji lwowskiej pozostało 13 kościołów, z tego dwa we Lwowie; M. TrofIMIAK, Świadectwo archidiecezji lwowskiej obrządku tacińskiego (Ukraina), [w:] Świadectwo Kościoła katolickiego w systemie totalitarnym Europy Środkowo-Wschodniej. Księga Kongresu Teologicznego Europy Środkowo-Wschodniej KUL, 11-15 sierpnia 1991, red. J. Nagórny [i in.], Lublin: RW KUL 1994, s. 211.

${ }^{5}$ Zgodnie z radzieckim systemem prawnym, aby rozpocząć starania o odzyskanie kościoła, należało uprzednio zarejestrować tzw. dwadcatkę. W jej skład wchodziło co najmniej 20 osób, które z ramienia i pod kontrolą władzy centralnej zarządzać miały majątkiem kościoła i które „zatrudniały” księdza, aby ten zaspokajał potrzeby religijne wiernych; J. SZYMAŃsKI, Dwadcatki - organy wykonawcze organizacji religijnych $w$ sowieckim systemie represji (Obwód Winnicki na Podolu, 1944-1964), „Roczniki Teologiczne” 50 (2003), z. 4, s. 171-173; J. SzYMAŃSKI, Kapłan katolicki jako inicjator $i$ koordynator środowisk polskich na Ukrainie, [w:] Funkcje i zadania elit w środowiskach polonijnych, red. J. Knopek, Toruń: Wydawnictwo Adam Marszałek 2006, s. 219-220; A. HLEBowicz, Katolicyzm w państwie sowieckim 1944-1992, Gdańsk: Wydawnictwo Stella Maris 1993, s. 137.

${ }^{6}$ Katolickie pismo o tematyce społeczno-kulturalnej, ukazujące się od 1945 r.
} 
Pierwsze z nich powróciły do wiernych już pod koniec 1988 r. Oddano wtedy kilka kościołów położonych na terenach sąsiadujących z diecezją przemyską. Jak przyznaje biskup Marcjan Trofimiak, „główny okres zwrotu świątyń Kościołowi katolickiemu rozpoczął się wiosną 1989 roku”" . Paradoksalnie przemiany demokratyczne, jakie na początku lat dziewięćdziesiątych miały miejsce na Ukrainie, proces ten znacznie przyhamowały. Już w 1990 r. dało się zauważyć, że nowe władze z coraz większym niepokojem patrzą na odradzające się życie religijne, zwłaszcza jeśli chodzi o katolików obrządku łacińskiego ${ }^{8}$. Doskonałym tego przykładem może być los kościoła św. Elżbiety we Lwowie, który mimo starań Polaków przekazany został grekokatolikom?.

Dodatkowo przełom lat osiemdziesiątych i dziewięćdziesiątych był okresem spontanicznego odradzania się polskości na Ukrainie. Co ciekawe, w większości przypadków odrodzenie to zostało poprzedzone walką o odzyskanie kościoła, która w sposób szczególny jednoczyła lokalne środowiska polonijne ${ }^{10}$. Całość zamyka rok 1991, kiedy to ogłoszona została niepodległość Ukrainy. Pomimo że proces zwrotu budynków kościelnych katolikom obrządku łacińskiego trwał nadal, nie osiągnął on już nigdy takiej skali jak w latach 1989-1990.

Nie jest możliwe omówienie tematu zwrotu kościołów na terytorium Ukrainy bez jednoczesnego nakreślenia, choćby w ogólnym zarysie, polityki władz radzieckich w stosunku do religii, która w interesującym nas okresie uległa istot-

\footnotetext{
${ }^{7}$ W. OSADCZY, Władyka Markijan. O historii i dniu dzisiejszym Kościoła katolickiego na Ukrainie z księdzem biskupem Marcjanem Trofimiakiem rozmawia Włodzimierz Osadczy, Lublin-Łuck: Wydawnictwo KUL 2009, s. 100.

${ }^{8}$ O. Rafał Kiernicki w trakcie jednego z wywiadów mówił: „ostatnio nic się nie zmieniło, nie odzyskaliśmy we Lwowie ani jednej świątyni. Władze cywilne, mimo tej odwilży, nie chcą nam oddać żadnego z kościołów [...]. My staramy się o oddanie kościoła, ale władze ukraińskie przekazują świątynie grekokatolikom albo innym wyznaniom wschodnio-ukraińskim” (K. RENIK, Podpolnicy. Rozmowy z ludźmi Kościoła na Litwie, Lotwie, Białorusi i Ukrainie 1990-1991, Warszawa: Oficyna Przeglądu Powszechnego 1991, s. 278).

${ }^{9}$ Kiedy już wszystkie dokumenty, niezbędne z formalnego punktu widzenia, były gotowe, a kościół przygotowany do zwrotu wiernym, zmieniły się lokalne władze. Postanowienie o przekazaniu świątyni zostało natychmiast anulowane, a kościół przekazano na potrzeby grekokatolików; W. OsADCZY, Wtadyka Markijan, s. 100-101.

${ }^{10}$ Tak było np. w Żółkwi, gdzie nielicznych przedstawicieli polskiej mniejszości narodowej połączyła początkowo walka o odzyskanie kościoła, następnie zaś część z tych osób zaangażowała się w utworzenie i działalność lokalnego oddziału Towarzystwa Kultury Polskiej Ziemi Lwowskiej. Ł. Joniec, Z działalności Towarzystwa Kultury Polskiej Ziemi Lwowskiej oddział w Żótkwi w latach 2003-2011, „HISTORIC@”. Czasopismo naukowe doktorantów Uniwersytetu Rzeszowskiego, 2016 nr 18, s. 61-62, czasopismo dostępne jest w wersji elektronicznej na stronie internetowej: http://www.ur.edu.pl/wydzialy/socjologiczno-historyczny/instytut-historii/czasopisma/historic/wydania [dostęp: 02.10.2017].
} 
nym zmianom. Musimy pamiętać, że większość działań miejscowych władz było wypadkową decyzji podejmowanych przez ich zwierzchników w Kijowie, a nierzadko w samej Moskwie. Tak też było z wszelkimi odstępstwami od dotychczasowej polityki państwa w stosunku do religii. Siłą rzeczy musiały one uzyskać najpierw akceptację czynników decydujących. Dlatego też dla lepszego zrozumienia problematyki poruszanej w niniejszym artykule, możliwie krótko przemiany te także zostaną scharakteryzowane. Oczywiście jedynie przez pryzmat tekstów publikowanych na kartach ,TP”.

Wszelkie informacje odnoszące się do interesującego nas tematu publikowane były zazwyczaj w dwóch działach „TP”, mianowicie „Kronika Religijna” („KR”) oraz „Ze Świata” („ZŚS”), ze znaczną przewagą tego pierwszego. Były to zazwyczaj krótkie, kilkuzdaniowe, ale bogate w treści komunikaty, na podstawie których powstała znaczna część tych rozważań. Właściwe, obszerne artykuły zasadniczo kwestie te omijały, skupiając się, jeżeli już, przede wszystkim na zachodzących w tym czasie w ZSRR zmianach na linii państwo-Kościól, ewentualnie omawiały aktualną sytuację katolików na tych terenach. Nieliczne artykuły dotyczyły starań o odzyskanie konkretnej parafii ${ }^{11}$.

ROK 1988

Analizę artykułów zamieszczonych w „TP” i poruszających interesującą nas problematykę rozpoczniemy od przytoczenia fragmentów tekstu zamieszczonego w czasopiśmie „Wiadomości Moskiewskie”, które cytuje autor wpisu w kronice „ZŚ". Wpis ten dotyczy kwestii odzyskania przez Cerkiew jednego z podmoskiewskich klasztorów. Jednocześnie wskazuje na pierwsze symptomy zmian polityki władz w stosunku do religii. „W minionym 70-leciu - pisze autor cytowanego artykułu - byliśmy bardziej skłonni burzyć i zamykać [...]”. Dalej wspominając o otwarciu wielu kościołów w ostatnim czasie, dodaje: „dogmatycy na wieść o tych faktach odczuwają swoisty rodzaj świętego oburzenia i przerażenia. $\mathrm{W}$ ich oczach polityka ta oznacza rezygnację $\mathrm{z}$ wielkich zasad i ustępstwo na rzecz Kościoła. Absolutnie niezdolni do spojrzenia z nowego punktu widzenia, w oparciu o nowe idee i przesłanki nie mogą zrozumieć, że ocenianie w naszych

\footnotetext{
${ }^{11} \mathrm{~W}$ artykule wykorzystano wybrane teksty publikowane na łamach „Tygodnika Powszechnego". Teksty dobierane były przez autora w sposób możliwie najszerzej obrazujący interesujące nas problemy.
} 
czasach stosunków Kościół - państwo wyłącznie z wrogiej pozycji jest głębokim i niebezpiecznym błędem" ${ }^{\prime 2}$.

Na rok 1988 przypadała rocznica 1000-lecia chrztu Rusi. Nieoczekiwanie na uroczyste obchody zaproszenie otrzymali przedstawiciele Watykanu. Jest to o tyle ciekawe, że dotychczas władze sowieckie bardzo nieufnie, jeśli nie wrogo wręcz, podchodziły do Stolicy Apostolskiej. Według oficjalnego kursu partyjnego, Watykan na liście największych wrogów ZSRR zajmował czołową pozycję. W osobach kapłanów katolickich widziano „szpiegów Watykanu”13 mających na celu ogłupianie społeczeństwa radzieckiego i nawracanie go z obranej przed kilkoma dekadami, jedynie słusznej drogi, mianowicie komunizmu. W krótkiej notatce „TP” informuje czytelnika, iż papież Jan Paweł II delegował na obchody swoich przedstawicieli. Wśród nich znalazł się między innymi Prymas Polski, kard. Józef Glemp ${ }^{14}$. Temat obchodów 1000-lecia chrztu Rusi kontynuowany był także w kolejnych egzemplarzach „TP”. W ostatnim czerwcowym numerze zamieszczono krótką relację z jej przebiegu. 13 czerwca sekretarz stanu Stolicy Apostolskiej, kard. Agostino Casaroli, został przyjęty przez M. Gorbaczowa. Spotkanie trwało półtorej godziny. Na zakończenie kard. A. Casaroli wręczył przywódcy ZSRR osobiste posłanie od Jana Pawła II ${ }^{15}$. Właściwe uroczystości rozpoczęły się 14 czerwca. Tego dnia kard. J. Glemp odprawił mszę świętą w jedynej katolickiej świątyni w Kijowie, w kościele pw. Podwyższenia Krzyża Świętego. Uroczystość zgromadziła ponad trzysta osób, w tym trzynastu księży głównie polskiego pochodzenia ${ }^{16}$. W „TP” z 14 sierpnia 1988 r. zamieszczono wypowiedź kard. Franza Koeniga, który z ramienia Stolicy Apostolskiej również uczestniczył w obchodach. Słowa te odnoszą się do sytuacji religijnej w ZSRR i warto je przytoczyć w całości. „Nie odniosłem wrażenia, żeby w tym kraju ateizm był głęboko zakorzeniony. Jest wprawdzie niemało ludzi, którzy określają się jako ateiści, ale robią to dlatego, żeby wyrazić swoje utożsamienie z kierow-

\footnotetext{
${ }^{12}$ Ze Świata, ,,Tygodnik Powszechny” 24 stycznia 1988, nr 4 (2013).

${ }^{13}$ R. DzwONKOwSKI, Leksykon duchowieństwa polskiego represjonowanego w ZSRR 19391988, Lublin: TN KUL 2003, s. 26.

${ }^{14}$ Kronika Religijna, Delegacja watykańska na uroczystości 1000-lecia chrztu Rusi, „Tygodnik Powszechny" 15 maja 1988, nr 20 (2029).

${ }^{15}$ Papież Jan Paweł II przekazał M. Gorbaczowowi list wraz z memorandum, w którym nakreślone zostały najistotniejsze problemy Kościoła katolickiego w ZSRR; R. DZwONKOwSKI, Polacy w Kościele katolickim na wschodzie (1939-2011), Toruń: Wydawnictwo Adam Marszałek 2011, s. 26.

${ }^{16}$ Kronika Religijna, Uroczystości 1000-lecia chrztu Rusi (c.d.), „Tygodnik Powszechny” 26 czerwca 1988, nr 26 (2035).
} 
nictwem państwowym i partyjnym. Prawdą jest, że w ZSRR w ostatnich dziesiątkach lat tkwiła propaganda, która wychowywała ludzi systematycznie do ateizmu i jest również prawdą, że każde publiczne wyznanie wiary spotykało się z potępieniem, ale za naszych dni jesteśmy świadkami powrotu religii do szerokich mas ludzkich tego kraju, zwłaszcza gdy idzie o młodzież"17. Wypowiedź ta jest o tyle ważna, że w pewien sposób wyjaśnia późniejsze żywiołowe odrodzenie religijne $\mathrm{w}$ państwie sowieckim $\mathrm{i}$ oddolne starania o rejestrację parafii katolickich. Katolicyzm w państwie sowieckim, wbrew zamiarom władz, nie został zniszczony, został jedynie zepchnięty do podziemia, by następnie w bardziej sprzyjających warunkach otwarcie zamanifestować swoją obecność w komunistycznej rzeczywistości.

W „TP” z 30 października zamieszczono kolejny komunikat świadczący o coraz większej tolerancji wobec religii w państwie sowieckim. I choć dziś może się wydawać, iż informacja w nim zamieszczona nie miała większego znaczenia w ówczesnych realiach politycznych, było zgoła inaczej. Autor kroniki „ZŚS” za radzieckim dziennikiem „Izwiestia” podaje mianowicie, że od 1 lipca istnieje możliwość wysyłania Pisma Świętego do państw radzieckich za pośrednictwem poczty. Dodatkowo informuje czytelnika o tym, iż władze postanowiły oddać katolikom katedrę w Wilnie, przed czterdziestoma laty zamienioną na galerię obrazów $^{18}$.

Wydany blisko miesiąc później „TP” wskazuje na kolejne wydarzenia, oznaczające istotne zmiany w podejściu władz radzieckich do spraw religii. Po raz pierwszy w dziejach ZSRR do jednej ze szkół średnich wprowadzona została nauka religii. Mowa tu o szkole w Rydze, gdzie środki na pensję pastora ewangelickiego pochodzą z funduszy państwowych. Zapowiedziano także, że w przyszłym roku możliwość nauczania religii zostanie rozszerzona na pozostałe działające w mieście gimnazja. Dodatkowo, koła kościelne informują, że w niektórych szkołach w ZSRR zezwolono na czytanie Biblii. Powodem takiej decyzji miało być - zdaniem władz - „lepsze zrozumienie rosyjskiej kultury i historii”. Ten sam „TP” donosi także o innym ważnym wydarzeniu. Otóż Rada Ministrów Litewskiej Socjalistycznej Republiki Radzieckiej zgodziła się poprzeć wniosek Ministerstwa Kultury i oddać wiernym w terminie do 1 marca 1989 r. kościół św. Kazimierza w Wilnie. W kościele tym znajdowało się ówcześnie

\footnotetext{
${ }^{17}$ Ze świata, „Tygodnik Powszechny” 14 sierpnia 1988, nr 33 (2042).

${ }^{18}$ Ze świata, ,Tygodnik Powszechny” 30 października 1988, nr 44 (2053).
} 
Muzeum Historii Religii i Ateizmu LSRR ${ }^{19}$. Kontynuacją tematyki związanej z sytuacją katolików w państwie litewskim był artykuł Józefy Hennelowej pt. W cieniu Rossy, w świattach Ostrej Bramy. Mimo iż artykuł ten nie dotyczy bezpośrednio państwa, które nas interesuje, to jednak omawia sytuację religijną w ZSRR oraz politykę władz w Moskwie, a co za tym idzie - odnosi się pośrednio do wszystkich jego republik, w tym Ukrainy, z tego też względu wart jest uwagi. Autorka tekstu zauważa między innymi wyraźne ożywienie religijne w Wilnie. „Teraz Kościół obecny jest w życiu publicznym, nazywany po imieniu, ma twarze hierarchów pokazywanych w telewizji, wzmiankowanych w prasie [...] i twarze dziesiątków i setek tysięcy wiernych masowo uczestniczących w nabożeństwach o charakterze wręcz manifestacyjnym". Wspomina ponadto o tabliczce umieszczonej przy wejściu do katedry, która zawiera informację, że świątynia wkrótce zostanie zwrócona wiernym ${ }^{20}$.

Tydzień później na łamach „TP” ukazał się tekst o. Wincentego Stanisława Paryny odnoszący się bezpośrednio do tematyki przez nas poruszanej. Artykuł ten, będący częściowo odpowiedzią na relację Ryszarda Terleckiego z jego podróży do Lwowa ${ }^{21}$, skupia się przede wszystkim na katedrze lwowskiej oraz pełniącym tam ówcześnie posługę ks. Władysławie Rafale Kiernickim. Ks. Władysław, znany powszechnie jako o. Rafał, na terenach archidiecezji lwowskiej jest postacią wprost legendarną 22 . W latach powojennych, kiedy większość kościołów została zamknięta, wierni z okolicznych miejscowości, oddalonych nierzadko o kilkadziesiąt kilometrów, na mszę świętą przyjeżdżali właśnie do katedry. „O. Rafał - pisze autor artykułu - nie ma życia prywatnego. Mieszka w jednym małym pokoju, nie ma telewizora, jego życiem jest praca kapłańska i posługa wiernym. Od lat, jak długo tam jest i dziś - pierwszy jest w katedrze już o godz. 6.30 do domu wraca dopiero na noc o godz. 21.00, a czasem po 22.00 [...]. Przez 39 lat pracy w katedrze ani razu nie miał tygodniowego urlopu, nie wyjeżdżał na wycieczki, nie był ani razu w Polsce [...]. Dzięki jego opiece duchowej jest już trzech wyświęconych księży z terenu Lwowa, a trzech innych jest w seminarium

\footnotetext{
${ }^{19}$ Ze świata, „Tygodnik Powszechny” 20 listopada 1988, nr 47 (2056).

20 J. Hennelowa, W cieniu Rossy, w świattach Ostrej Bramy, „Tygodnik Powszechny” 4 grudnia 1988, nr 49 (2058).

${ }^{21}$ R. TERLECKI, Powrót do Lwowa, ,Tygodnik Powszechny” 23 października 1988, nr 43 (2052).

${ }^{22}$ Szerzej zob. m.in. R.W. KIERNICKI, Duszpasterz mimo woli, [w:] Wytrwać i przetrwać jak Bóg daje. Świadkowie Kościoła rzymskokatolickiego na Ukrainie Sowieckiej 1917-1991, red. J. Wołczański, Kraków: Wydawnictwo UNUM 2010, s. 253-306; J. KRĘTOSZ, Katedra obrzadku Łacińskiego we Lwowie i jej proboszcz o. Rafat Kiernicki OFM Conv w latach 1948-1991, Katowice: UŚ 2003; R. DZWONKOwSKI, Leksykon duchowieństwa polskiego, s. 318-319.
} 
w Rydze"23. Z dalszej części artykułu dowiadujemy się ponadto o talentach organizatorskich o. Rafała. Dzięki jego staraniom udało się także odnowić budynek katedry, miał też znaczny udział wraz z ks. Ludwikiem Kamilewskim w odzyskaniu wielu parafii na terenie zachodniej Ukrainy ${ }^{24}$.

Kontynuacją nawiązanych przez kard. J. Glempa w czasie obchodów 1000-lecia Chrztu Rusi oficjalnych kontaktów Kościoła katolickiego z władzami radzieckimi była wizyta w Moskwie sekretarza Episkopatu Polski, biskupa Jerzego Dąbrowskiego. O samej wizycie oraz poruszanych w czasie niej kwestiach informuje nas komunikat Biura Prasowego Episkopatu Polski, zamieszczony na łamach tygodnika w „KR”. Biskup J. Dąbrowski spotkał się między innymi z przewodniczącym Rady ds. Religii przy Radzie Ministrów ZSRR. W trakcie spotkania omawiano kwestie poruszane już podczas wcześniejszych wizyt przedstawicieli polskiego Kościoła, skupiając się między innymi na potrzebie zapewnienia posługi duszpasterskiej Polakom przebywającym w ZSRR ${ }^{25}$. Zarówno to, jak i poprzednie spotkania były bardzo istotne, biorąc pod uwagę relacje duchowieństwa z przedstawicielami administracji państwowej. Oznaczały wyraźną zmianę sytuacji Kościoła katolickiego oraz samych Polaków w ZSRR. Pozwoliły poruszyć tematy od dawna wyjęte z oficjalnej dyskusji, tym bardziej że partnerami w rozmowach byli przedstawiciele najwyższych władz radzieckich, w rękach których nierzadko leżał los parafii oddalonych nawet o tysiące kilometrów od stolicy państwa radzieckiego.

ROK 1989

$\mathrm{Na}$ początku roku 1989 w „KR” „TP” opublikowana została informacja w pewien sposób podsumowująca to, co działo się w ZSRR w odniesieniu do religii $\mathrm{w}$ roku poprzednim. Przytoczono tam słowa prawosławnego metropolity Filareta, który podczas pobytu w Genewie (gościł tam na zaproszenie Światowej Rady Kościołów), w trakcie swojego przemówienia oświadczył, iż w roku 1988 w ZSRR dla kultu religijnego udostępniono 723 kościoły, z czego 200

\footnotetext{
${ }^{23}$ W.S. PARYNA, O. Rafat Kiernicki-duszpasterz w Katedrze Lwowskiej, „Tygodnik Powszechny" 11 grudnia 1988, nr 50 (2059).

24 Tamże.

${ }^{25}$ Komunikat Biura Prasowego Episkopatu Polski, Podróż biskupa Jerzego Dąbrowskiego, zastępcy sekretarza Episkopatu Polski do Moskwy, „Tygodnik Powszechny” 11 grudnia 1988, nr 50 (2059).
} 
znajdowało się na terytorium Ukrainy. Dodatkowo poinformował zgromadzonych, że władze państwowe wydały pozwolenie na otwarcie czterech nowych seminariów duchownych Kościoła prawosławnego, wskazując tym samym na forum międzynarodowym, że polityka walki z religią w ZSRR powoli traci rację bytu $^{26}$. W kolejnym wydaniu „TP” czytelnikowi przekazano kilka istotnych danych statystycznych. Otóż zgodnie z liczbami podanymi przez autorów kroniki „ZŚ", na jedynym seminarium duchownym Kościoła katolickiego w ZSRR w Rydze, w roku akademickim 1987/88 nauki pobierało 80 alumnów, w tym 24 Polaków. W tym czasie na terytorium ZSRR (nie licząc Litwy i Łotwy) czynnych było 257 parafii katolickich, w których posługę pełniło 127 kapłanów ${ }^{27}$.

Tydzień później na łamach „TP” ukazała się relacja z wizyty ks. Aleksandra Mena w szkole nr 67 w Moskwie. Co ciekawe, ks. Aleksander był pierwszym duchownym, który od 70 lat oficjalnie przekroczył próg tej szkoły. Informacja o spotkaniu księdza z młodzieżą przedrukowana została także w prasie francuskiej i włoskiej ${ }^{28}$. Ten sam numer pisma donosi, że administrator apostolski archidiecezji wileńskiej na Litwie biskup Julijonas Steponavicius w 1961 r. skazany na zesłanie, otrzymał od władz oficjalne pozwolenie na powrót do Wilna i podjęcie sprawowanych przez siebie przed wyjazdem funkcji ${ }^{29}$. Temat ten kontynuowany był także w następnym wydaniu „TP”, w którym podano, iż biskup zapowiedział, że pierwszym aktem jego urzędowania będzie rekonsekracja katedry, zamienionej na galerię obrazów ${ }^{30}$. Ponowne poświęcenie katedry miało miejsce 5 lutego, a całą uroczystość transmitowała litewska telewizja ${ }^{31}$.

W „TP” z 2 kwietnia 1989 r. w dziale „KR” zamieszczona została informacja (za agencją TASS), że w dniu św. Józefa we wsi Tszczeniec (Trzcieniec) na Ukrainie zachodniej, niedaleko granicy polskiej, miejscowi katolicy obrządku łacińskiego odzyskali kościół pw. św. Józefa. Ponadto władze podjęły już decyzję o rejestracji parafii w Drohobyczu. Na swoją kolej czekali parafianie z Rudek,

\footnotetext{
${ }^{26}$ Kronika Religijna, Otwarcie nowych świątyń i seminariów w ZSRR, „Tygodnik Powszechny” 8 stycznia 1989, nr 2 (2063).

${ }^{27}$ Ze Świata, „Tygodnik Powszechny” 15 stycznia 1989, nr 3 (2064).

${ }^{28}$ S. Musiat, Szkoła nr 67 w Moskwie pyta o Boga, ,Tygodnik Powszechny” 22 stycznia 1989, nr 4 (2065).

${ }^{29}$ Ze Świata, „Tygodnik Powszechny” 22 stycznia 1989, nr 4 (2065).

${ }^{30}$ Ze Świata, „Tygodnik Powszechny” 29 stycznia 1989, nr 5 (2066).

${ }^{31}$ Kronika Religijna, Poświęcenie katedry w Wilnie, ,Tygodnik Powszechny” 19 lutego 1989, nr 8 (2069).
} 
którzy nie otrzymali jeszcze oficjalnej decyzji o zwrocie miejscowego kościoła ${ }^{32}$. W tym samym „TP” przytoczone zostały słowa kard. Henryka Romana Gulbinowicza, który w swoim przemówieniu na spotkaniu Prymasowskiej Rady Społecznej i Laikatu Polonii w Rzymie odniósł się do kwestii stosunku państwa sowieckiego do religii. „Polityka władz radzieckich przez dziesiątki lat zmierzała do wyniszczenia katolicyzmu i likwidacji parafii. Parafie pozbawione były kościoła, gdy umierał ksiądz proboszcz. Nie było bowiem możliwości kształcenia następców. Teraz te możliwości są większe [...]. Lata administracyjnych prześladowań nie złamały ducha wiary. Tam, gdzie jest to możliwe, wspólnoty parafialne odzyskują kościoły, zamknięte całymi latami. Teraz pierwszy raz od dawna pojawiła się nadzieja" ${ }^{33}$. Słowa te po raz kolejny wypowiedziane na forum międzynarodowym, potwierdzały obserwowaną już od początku ubiegłego roku zmianę polityki komunistycznych władz wobec Kościoła katolickiego i szerzej wobec religii.

Tydzień później czytelnik „TP” miał możliwość zapoznania się z krótką relacją z obchodów świąt wielkanocnych w katedrze lwowskiej, która w niedzielę Zmartwychwstania Pańskiego na porannej mszy św. niemal po brzegi wypełniła się wiernymi. Uroczystościom przewodniczył ks. L. Kamilewski, współpracownik o. Rafała Kiernickiego. Podczas kazania ks. Ludwik wyraził zadowolenie z korzystnych przeobrażeń, jakie zachodzą w stosunkach pomiędzy Kościołem a państwem. Katolicy mieszkający w rejonie Lwowa zogromną radością odbierają wiadomości o zwrocie kolejnych świątyń katolickich. Jak podkreślił ks. Ludwik, obecne święta obchodzone są w dwunastu parafiach znajdujących się w rejonie lwowskim, mimo iż do niedawna było ich 9, w tym dwie w samym Lwowie. Co istotne, zdaniem duchownego, na dobrej drodze do odzyskania świątyń są także wierni winnych miejscowościach, między innymi w Sądowej Wiszni, Pomorzanach, Drohobyczu, Rudkach, Baryszu i Myślatyczu³. W kwestiach tych ks. Ludwik był niewątpliwie osobą najlepiej rozeznaną, bowiem właśnie on brał czynny udział w odzyskiwaniu wielu parafii na terenie byłej archidiecezji lwowskiej.

\footnotetext{
32 Kronika Religijna, Zwrot świątyni katolickiej w archidiecezji lwowskiej, „Tygodnik Powszechny" 2 kwietnia 1989, nr 14 (2075).

${ }^{33}$ Kronika Religijna, O katolikach w ZSRR, „Tygodnik Powszechny” 2 kwietnia 1989, nr 14 (2075).

${ }^{34}$ Kronika Religijna, Wielkanoc w katedrze lwowskiej, „Tygodnik Powszechny” 9 kwietnia 1989, nr 15 (2076).
} 
W „TP” z 21 maja autor posługujący się kryptonimem W. S. w kilkunastozdaniowej notatce pt. Światynie katolickie na terenie od Mościsk do Zbrucza i Dniestru dokonuje podsumowania $\mathrm{z}$ dotychczasowego przebiegu procesu odzyskiwania parafii katolickich na terenie Ukrainy oraz wymienia księży pełniących posługę w działających już kościołach. I tak swoją relację rozpoczyna od Mościsk, gdzie funkcje kapłańskie wykonuje ks. Józef Legowicz. Dodatkowo ks. Józef pełni posługę kapłańską w innych miejscowościach, tzn. Lipniki, Pnikut i Trzciniec (Trzcieniec). Kolejne kościoły katolickie w rejonie Mościsk są remontowane przez wiernych, mianowicie świątynie w Sądowej Wiszni, Myślatyczach, Balicach i Radocheńcach. Jeśli chodzi o Lwów, posługę w katedrze pełni o. Rafał, którego wspomagają dwaj młodsi księża, ks. L. Kamilewski oraz ks. Gerard Liryk. Drugi czynny lwowski kościół katolicki, kościół św. Antoniego obsługiwany jest przez ks. Kazimierza Mączyńskiego, który na stałe mieszka w Samborze i dodatkowo dojeżdża jeszcze do Stryja. W Złoczowie natomiast pracuje dwóch kapłanów, osiemdziesięcioletniego ks. Jana Cieńskiego wspomaga młodszy ks. Piotr Marko ${ }^{35}$.

Autor powyższego artykułu przekazuje także ważną informację dotyczącą ponownego poświęcenia kolejnej świątyni katolickiej odzyskanej przez wiernych na Ukrainie. Chodzi mianowicie o wspominany już przez nas kościół w Rudkach. Uroczystość odbyła się 13 maja 1989 r., wcześniej świątynia pełniła funkcję magazynu. Przekazany katolikom został także kościół Króla Chrystusa w Stanisławowie (od 1962 r. Iwano-Frankowsk) ${ }^{36}$. Nadal nierozwiązana pozostawała jednak sprawa zwrotu kościoła parafialnego w Drohobyczu. W Krzemieńcu - jedynej placówce duchownej na terenie byłej diecezji łuckiej - posługę duszpasterską pełni ks. Józef Trofimiuk ${ }^{37}$.

Kolejna część tekstu dotyczyła bardzo istotnego problemu, to znaczy kwestii niewystarczającej liczby kapłanów katolickich na Ukrainie $^{38}$. Na domiar złego większość duchownych jest już w podeszłym wieku i mimo ogromnego poświęcenia nie są w stanie pokonać kilkuset kilometrów, aby co tydzień dotrzeć do

\footnotetext{
${ }^{35}$ Kronika Religijna, Świątynie katolickie na terenie od Mościsk do Zbrucza i Dniestru, „Tygodnik Powszechny” 21 maja 1989, nr 21 (2082).

${ }^{36}$ Podobnie jak autorzy analizowanych tekstów, używać będziemy przeważnie polskich nazw miejscowości i województw, pomimo że w niektórych przypadkach nazwy te oficjalnie już nie funkcjonowały.

${ }^{37}$ Kronika Religijna, Światynie katolickie.

${ }^{38}$ Sytuacja ta charakterystyczna była nie tylko dla Ukrainy, ale dla wszystkich krajów wchodzących w skład ZSRR. Była ona konsekwencją polityki zamykania seminariów duchownych oraz ograniczania dostępu do tych, które udało się utrzymać przy życiu.
} 
wiernych. Dlatego też tam, gdzie nie ma księdza w niedzielę i święta, wierni na ogół sami zbierają się w kościele. Zapalają świece, ustawiają na ołtarzu kielich, mszał oraz ornat i własnymi siłami „odprawiają” mszę św., modląc się i śpiewając pieśni religijne ${ }^{39}$.

Blisko miesiąc później na łamach „TP” ukazało się uzupełnienie do wspomnianej notatki autorstwa Eugenii Noworolskiej. Mianowicie jej zdaniem w Złoczowie ks. J. Cieńskiemu w wypełnianych przez niego obowiązkach duszpasterza pomaga ks. Ludwik Marko. Dodatkowo przypomina, iż czynne są już świątynie w Dobromilu oraz Nowym Mieście, gdzie posługę pełnią kolejno: ks. Piotr Sawczak oraz ks. Jan Szetela. W województwie tarnopolskim ${ }^{40}$ czynne są kościoły w Borszczowie, Hałuszczyńcach k. Tarnopola, a ponadto Połupanówce k. Skałatu. 25 marca wiernym została oddana także świątynia w Czortkowie. We wszystkich czterech parafiach posługę pełni ks. Marek Trofimiak, który jednocześnie jest proboszczem kościoła w Krzemieńcu. W posłudze wspomaga go wikariusz ks. Michał Jaworski ${ }^{41}$.

W tym samym wydaniu „TP” w rubryce „ZŚ, opublikowana została informacja o staraniach podejmowanych przez reprezentantów Kościoła greckokatolickiego, celem legalizacji ich struktur kościelnych. Uczestniczący w rozmowach ze strony rządowej Jurij Christoradnow oświadczył, iż „legalizacja ukraińskiego Kościoła katolickiego obrządku bizantyjskiego mogłaby doprowadzić do sporów i zatargów między katolikami a prawosławnymi, a w przypadku Kościoła greckokatolickiego na Ukrainie chodzi o bardzo małą grupę". Reprezentant strony kościelnej biskup Pawlo Wasylyk odpowiedział, że katolicy i prawosławni żyli przez całe wieki na Ukrainie w spokoju i przyjaźni, ponadto wskazał, że nie chodzi tu wcale o małą grupę wiernych ${ }^{42}$. Jak się w przyszłości okaże, twierdzenia Christoradnowa wcale nie były bezpodstawne, nieporozumienia na linii katolicyzm-prawosławie nie będą rzadkością. Co gorsza, dochodzić będzie także do dość ostrych sporów pomiędzy dwoma odłamami katolicyzmu, nie tylko w kwestiach dotyczących zwrotu budynków kościelnych ${ }^{43}$.

\footnotetext{
${ }^{39}$ Kronika Religijna, Świątynie katolickie.

${ }^{40}$ Zgodnie z obowiązującym na Ukrainie podziałem administracyjnym, odpowiednikiem województwa jest область - oblast.

${ }^{41}$ E. NoworolsKa, Uzupetnienie do notatki w Kronice Religijnej: Kronika Religijna, Światynie katolickie na terenie od Mościsk do Zbrucza i Dniestru, „Tygodnik Powszechny” 18 czerwca 1989, nr 25 (2086).

${ }^{42}$ Ze Świata, „Tygodnik Powszechny” 18 czerwca 1989, nr 25 (2086).

${ }^{43}$ Szerzej zob. m.in. W. OsADCZY, Kościoła łacińskiego na Ukrainie dole i niedole. Doświadczenie, dzień dzisiejszy, problemy i perspektywy, [w:] Kościót katolicki na Wschodzie w warunkach
} 
W „TP” z 6 sierpnia ukazał się interesujący wywiad Macieja Kozłowskiego z ks. biskupem Marianem Jaworskim, administratorem apostolskim archidiecezji lubaczowskiej. W trakcie rozmowy dziennikarz, wskazując na przykład unormowania sytuacji kościoła w archidiecezji wileńskiej, zapytał biskupa M. Jaworskiego, czy podobna sytuacja w najbliższym czasie może mieć miejsce na Ukrainie. Mimo iż biskup z oczywistych powodów nie był w stanie odpowiedzieć na tak postawione pytanie, odniósł się do aktualnej sytuacji katolików za wschodnią granicą Polski. „Obecnie - powiedział biskup - zwłaszcza w ostatnim roku, stały się możliwe częste kontakty z wiernymi po drugiej stronie granicy. Księża z radzieckiej Ukrainy przyjeżdżają do Polski, nasi księża coraz częściej wyjeżdżają na wschód. To bardzo dobrze. Ja sam nie miałem jeszcze okazji do wyjazdu. Po ostatniej rozmowie w ambasadzie ZSRR nie otrzymałem odmowy, lecz poradzono mi czekać [...]. Moją powinnością jako biskupa jest troska o wiernych niezależnie od tego gdzie mieszkają [...]. Ale jak powiadam, cierpliwie czekam i jestem dobrej myśli, tym bardziej, że ostatni zwłaszcza rok przyniósł wiele zmian na dobre" ${ }^{\text {"4 }}$.

Kolejny numer „TP” przyniósł dalsze pomyślne wieści płynące zza naszej wschodniej granicy. 24 czerwca 1989 r. miało miejsce otwarcie kolejnego kościoła katolickiego, tym razem w dawnej stolicy województwa - Stanisławowie. Proboszczem kościoła pw. Chrystusa Króla został wikariusz pochodzący z Kijowa, ks. Kazimierz Halimurka. Od chwili przekazania kościoła do dnia uroczystego otwarcia, w samym kościele jak i na placu wokół niego trwały intensywne prace porządkowe. Ksiądz proboszcz wraz z grupą parafian uporządkował i udekorował kościół tak, aby godnie uczcić tę niezwykle podniosłą chwilę w życiu lokalnej wspólnoty rzymskokatolickiej. Uczestniczyło w niej wielu gości, między innymi pielgrzymi z Sambora, Krzemieńca, Stryja, Drohobycza czy Rudek. Przybyli także liczni duchowni: ks. Jan Olszański (Manikowice), ks. K. Mączyński (Sambor), ks. L. Kamilewski (Lwów), ks. J. Legowicz (Mościska) oraz wielu innych. Łącznie mszę św. koncelebrowało ponad dwudziestu księży. Oczywiście nie zabrakło także gości z Polski, wspierających swoich rodaków

totalitaryzmu i posttotalitaryzmu, red. A. Gil, W. Bobryk, Siedlce-Lublin: Wydawnictwo Akademii Podlaskiej 2010, s. 95 n.

${ }^{44}$ Kościót na kresach. Z księdzem biskupem Marianem Jaworskim administratorem apostolskim archidiecezji w Lubaczowie rozmawia Maciej Kozłowski, „Tygodnik Powszechny” 6 sierpnia 1989, nr 32 (2093). 
z Ukrainy w ich staraniach o powrót do polskości. Niemal cały kościół wypełnił się wiernymi, zajęte zostały nawet nawy i balkony ${ }^{45}$.

Od samego początku starań o zwrot parafii rzymskokatolickich Polacy na Ukrainie mogli liczyć na pomoc ze strony swych rodaków. O jednym z takich przedsięwzięć informuje nas „TP” z 29 października 1989 r. Z apelem o pomoc duchowną i materialną dla rodaków za wschodnią granicą wystąpił tym razem ordynariusz przemyski biskup Ignacy Tokarczuk. Apel ten oprócz pomocy materialnej, skutkował także pomocą personalną. Tego roku bowiem z diecezji przemyskiej udało się do stałej pracy na Ukrainę sześciu kapłanów. Jak zapewniają władze kościelne, ta forma pomocy będzie kontynuowana w następnych latach $^{46}$. Wiadomość ta była bardzo istotna, biorąc pod uwagę, iż brak księży jak już wspominano - okazał się jednym z największych problemów odradzającego się w ZSRR życia religijnego.

Następne wydanie „TP” przynosi informację świadczącą o tym, jak mocno przywiązanie do swych rodzinnych stron tkwiło w Polakach wysiedlonych po wojnie z terenów, które weszły w skład USRR. Na odpust do niedawno odzyskanego kościoła w Rudkach udali się pięcioma autokarami dawni parafianie, którzy po wojnie wysiedleni zostali do Polski. Pielgrzymkę zorganizował ks. Stanisław Draguła, proboszcz parafii Najświętszego Serca Pana Jezusa w Niwniku (nieopodal Oławy), pochodzący również z parafii Rudki. Większość Polaków wysiedlonych po wojnie z Rudek osiedliła się w okolicach Oławy, Wrocławia, Głogowa, Żar i Lubina ${ }^{47}$.

Dwa tygodnie później na łamach „TP” ukazał się kolejny artykuł poświęcony odzyskaniu zamkniętego po wojnie kościoła katolickiego. Tym razem do wiernych powróciła historyczna kolegiata w Żółkwi ${ }^{48}$, stanowiąca swoiste mauzoleum oręża polskiego oraz związanych z Żółkwią rodów Żółkiewskich i Sobieskich ${ }^{49}$. 29 października o. Rafał dokonał ponownego poświęcenia kolegiaty pw. św. Wawrzyńca. Oprócz niego we mszy św. uczestniczyło wielu kapłanów pols-

\footnotetext{
${ }^{45}$ Kronika Religijna, Uroczystość otwarcia Kościoła pw. Chrystusa Króla w Stanistawowie, „Tygodnik Powszechny” 13 sierpnia 1989, nr 33 (2094).

${ }^{46}$ Kronika Religijna, Diecezja przemyska na rzecz wiernych w ZSRR, „Tygodnik Powszechny” 29 października 1989, nr 44 (2105).

${ }^{47}$ Kronika Religijna, Dawni parafianie z Rudek pielgrzymuja do ZSRR, „Tygodnik Powszechny" 5 listopada 1989, nr 45 (2106).

${ }^{48}$ W latach 1951-1991 obowiązywała nazwa Nesterów, od 1991 r. - Жовква, Żowkwa.

${ }^{49}$ Szerzej zob. Ł. JoNIEC, Powojenna sytuacja Kościoła katolickiego na terenach bytego województwa lwowskiego na przykładzie losów kolegiaty żótkiewskiej, „Studia Gdańskie” 35(2014), s. $207-$ 224. Tekst artykułu dostępny jest ponadto na stronie internetowej: http://studiagdanskie.diecezja.gda. pl /index.php/wydanie/tom-xxxv-2014/ [dostęp: 02.10.2017].
} 
kich z Ukrainy oraz księży z Polski, między innymi dominikanin Adam Studziński, kapelan spod Monte Cassino. Ponadto autor notatki informuje czytelnika o kolejnych przekazanych katolikom świątyniach na Ukrainie. Do wiernych wróciły kościoły w Strusowie, Jezierzanach, Rydodubach, Skale i Mikulińcach. Dwa ostatnie znajdują się w stanie ruiny i doprowadzenie ich do stanu używalności wymaga ogromnych nakładów finansowych. W najbliższym czasie do wiernych mają powrócić także świątynie w Łosiaczu i Zbarażu ${ }^{50}$.

We wspomnianym wywiadzie biskup M. Jaworski powiedział, że cierpliwie czeka, aż nadarzy się możliwość wyjazdu na Ukrainę. Możliwość taka zaistniała pod koniec października 1989 r., niemal po rocznych staraniach, a ks. biskup natychmiast z niej skorzystał. Wizyta duszpasterska biskupa M. Jaworskiego w archidiecezji lwowskiej odbyła się w dniach 30 października - 13 listopada. Zaraz po przekroczeniu granicy powitali go księża pracujący na terenie archidiecezji lwowskiej. W trakcie przejazdu do Lwowa ks. biskup odwiedził parafian w Mościskach, zaś po przyjeździe do Lwowa przewodniczył mszy św. odprawianej w katedrze. W następnych dniach biskup Jaworski odprawił mszę św. w kościołach w Samborze, Żółkwi, Pałupanówce (Połupanówce), Krzemieńcu, Czorykowie, Borszczowie, Stanisławowie, Szczercu, Stryju oraz Mościskach. Ponadto odwiedził te kościoły, które aktualnie były remontowane przez wiernych, między innymi w Sądowej Wiszni. Poświęcił także niedawno odremontowany kościół w Żydaczowie ${ }^{51}$.

Jak podkreśla autor tekstu, ks. Marian Buczek (kapelan i wicekanclerz Kurii Metropolitarnej w Lubaczowie), który towarzyszył biskupowi na Ukrainie, w trakcie spotkań z wiernymi dało się zauważyć, że głównym problemem lokalnych wspólnot katolickich jest brak wystarczającej liczby księży. Na terenie archidiecezji lwowskiej pracowało w tym czasie jedynie jedenastu księży, z czego teren województwa stanisławowskiego obsługiwał jeden kapłan, a województwa tarnopolskiego dwóch. Na teren województwa lwowskiego przypadło tylko ośmiu księży. Odległość pomiędzy poszczególnymi parafiami wynosiła od 30 do 100 km, co w dużym stopniu utrudniało księżom wykonywanie funkcji sakralnych. Kolejnym problemem był stan zwracanych wiernym kościołów. Większość z nich - jak już wspomniano - znajdowało się w bardzo złym stanie, bez wstawienia okien i remontu dachów, wszelkie prace renowacyjne we wnętrzach świątyń nie miały większego sensu. Jak podkreśla ks. Buczek, w wielu miejscowościach pa-

\footnotetext{
${ }^{50}$ Kronika Religijna, Poświęcenie Kościoła $w$ Żótkwi w archidiecezji lwowskiej, „Tygodnik Powszechny" 19 listopada 1989, nr 47 (2108).

${ }^{51}$ Kronika Religijna, M. BUCZEK, Wizyta duszpasterska biskupa Mariana Jaworskiego na terenie metropolii lwowskiej (30. X-13. XI), ,Tygodnik Powszechny” 3 grudnia 1989, nr 49 (2110).
} 
rafianom pomagają polscy pracownicy Energopolu, którzy swój wolny czas poświęcają na remont świątyń i porządkowanie polskich cmentarzy. 12 listopada biskup M. Jaworski odprawił pożegnalną mszę św. w katedrze lwowskiej. Obecni na niej byli niemal wszyscy kapłani z tamtych terenów, a także bardzo liczne grono wiernych. Na pożegnanie duchowny życzył wiernym, aby nie zważając na trudności, nadal trwali w wierze katolickiej ${ }^{52}$.

ROK 1990

W połowie stycznia w „TP” $\mathrm{w}$ dziale „ZŚ zarejestrowanych w ubiegłym roku w ZSRR nowych wspólnot religijnych. I tak od stycznia do listopada liczba ta sięgnęła blisko 3200 gmin religijnych różnych wyznań. Ogółem w tym czasie w całym ZSRR zarejestrowanych było ich ponad 16 tysięcy, w tej liczbie znajdowało się ponad 1300 wspólnot katolickich ${ }^{53}$. Liczby te potwierdzają wcześniejsze doniesienia o żywiołowym odrodzeniu życia religijnego w ZSRR.

Tydzień później „TP” donosił o kolejnej wizycie biskupa M. Jaworskiego na Ukrainie. Kulminacyjnym elementem wizyty była odprawiona przez niego Pasterka w katedrze lwowskiej; pierwsza taka msza celebrowana przez duchownego tej rangi od 1945 r. Duszpasterska wizyta za wschodnią granicą była też okazją do poświęcenia kolejnych parafii odzyskanych przez wiernych na Ukrainie zachodniej. Tym razem biskup zaszczycił swą wizytą mieszkańców Kamionki Strumiłowej, Bóbrki oraz przygranicznej Rawy Ruskiej. W każdej ze wspomnianych uroczystości uczestniczyły rzesze wiernych ${ }^{54}$.

Na początku lutego na kartach „TP” ukazała się niezwykle ciekawa rozmowa dwóch duchownych - o. Pawła Kozackiego oraz o. Pawła Malińskiego. Dotyczyła ona warunków, w jakich aktualnie funkcjonuje Kościół katolicki na Ukrainie. Na pytanie o zmianę sytuacji katolików na Ukrainie w ostatnim czasie, o. Maliński, który miał możliwość jej obserwowania przez blisko trzy miesiące,

\footnotetext{
52 Tamże

${ }^{53}$ Ze świata, „Tygodnik Powszechny” 14 stycznia 1990, nr 2 (2116).

${ }^{54}$ Kronika Religijna, Pasterka we Lwowie, ,Tygodnik Powszechny” 21 stycznia 1990, nr 3 (2117). W tym samym numerze zamieszczony został komunikat, podpisany przez kard. Glempa, informujący o powołaniu przez Episkopat Polski zespołu pomocy kościelnej dla katolików w Związku Radzieckim. Zespół ten miał przede wszystkim koordynować pomoc podejmowaną przez poszczególne diecezje i zgromadzenia zakonne, ale także w porozumieniu z kapłanami zza wschodniej granicy oraz władzami radzieckimi organizować pomoc zarówno materialną, jak i osobową; J. GLEMP, Zespót pomocy kościelnej dla katolików w ZSRR, „Tygodnik Powszechny” 21 stycznia 1990, nr 3 (2117).
} 
odpowiedział w następujący sposób „Ludzie przestali się bać. Przed kilkoma laty nikomu nie śniło się, że można dopominać się zwrotu kościoła w Stanisławowie czy Drohobyczu. Dziś w Stanisławowie jest otwarty kościół, a w Drohobyczu 400 ludzi walczy o zwrot ich świątyni. Nic nie dzieje się samo, wszystko trzeba wymusić u władz lokalnych, a jak nie, to u centralnych w Moskwie. Część zmian dokonała się metodą faktów dokonanych [...]. Zmienia się dużo, ale ludzie żyją pod presją czasu: »Trzeba kuć żelazo póki Gorbaczow«, mało kto wierzy w trwałość pierestrojki" ${ }^{, 55}$.

W dalszej części rozmowy o. Maliński zwraca uwagę na trzy cechy - jego zdaniem - charakterystyczne dla tamtejszego Kościoła. Po pierwsze - zachwyciło go przywiązanie ludzi do wiary, pomimo szeroko zakrojonej polityki ateizacji. Nie są rzadkością sytuacje, kiedy można zobaczyć „kilkuset ludzi tłoczących się wokół ołtarza w zniszczonej świątyni, która przez ostatnie 30 lat służyła jako magazyn nawozów sztucznych tamtejszego kołchozu". Po drugie - elementem wyróżniającym tamtejszych katolików była gotowość do poświęceń. „Trzeba wspomnieć o ludziach, którzy na niedzielną mszę świętą jadą po 100-150 km albo idą piechotą po $20 \mathrm{~km}$, a potem pokonują tę samą drogę wracając do domu". Kolejną cechą właściwą dla wiernych mieszkających na Ukrainie jest świeżość ich podejścia do religii. „Tam zamykali ludziom kościoły, wywozili księży. Oni przez dziesięciolecia czekali. Teraz, gdy świątynie są otwierane, ludzie, chociaż nie wiedzą o wierze zbyt wiele, to bardzo angażują się w Kościół, bardzo im na nim zależy. Jest w ludziach poczucie, że oni ten Kościół tworzą, że on jest ich własnością",56.

Dalej o. Maliński podkreśla ogromne zaangażowanie duchownych sprawujących swą posługę na terenie Ukrainy. Ich życie to nieustanny bieg pomiędzy kościołem, cmentarzem i placem budowy, a dzień pracy nierzadko zamyka się w osiemnastu godzinach. W wywiadzie poruszono także kwestię, która po dziś dzień będzie wywoływać gorące spory, mianowicie kwestię języka w liturgii ${ }^{57}$. O. Maliński wspomina sytuację, kiedy Polacy zbojkotowali mszę św. odprawianą

\footnotetext{
${ }^{55}$ P. KoZACKI, Zeschła ziemia... rozmowa o sytuacji kościoła na Ukrainie, „Tygodnik Powszechny" 4 lutego 1990, nr 5 (2119).

${ }^{56}$ Tamże.

${ }^{57}$ Zob. szerzej m.in.: R. Dzwonkowski SAC, O. Gorbaniuk, J. Gorbaniuk, Postawy katolików obrzadku łacińskiego na Ukrainie wobec języka polskiego, Lublin 2001; R. DzWONKOwsKI, Polacy w Kościele katolickim w krajach bytego ZSRR, [w:] Polskie odrodzenie na Wschodzie. Materiaty $z$ międzynarodowej konferencji naukowej nt. „Polacy w procesie transformacji systemowej i ustrojowej krajów byłego Zwiazku Radzieckiego” zorganizowanej w Siedlcach 16 listopada 1998 roku, red. A. Bobryk, J. Jaroń, Siedlce: Wydawnictwo Akademii Podlaskiej 1999, s. 174-180.
} 
w języku ukraińskim, obecny na niej był tylko kapłan i jeden ministrant. „Wobec takiej mszy niechętni są Polacy, którzy przez wiele lat bronili się przed rusyfikacją i ukrainizacją, a jedyną ostoją polskości był dla nich Kościół. Jeżeli teraz ten sam Kościół wprowadza język ukraiński do liturgii, to dla dotychczasowych wiernych jest to niemiły zgrzyt" $"$.

Charakterystyczne dla tych terenów - zdaniem o. Malińskiego - jest także łączenie i naprzemienne używanie dwóch pojęć - „katolik” i „Polak”. Sytuacja ta ma głębokie konotacje historyczne, bowiem na tych terenach wyznanie rzymskokatolickie zasadniczo pokrywało się z przynależnością do narodu polskiego. Ukraińcy - dawniej Rusini - należeli przeważnie do Kościoła greckokatolickiego ewentualnie Cerkwi prawosławnej. „Przygotowywałem pewnego razu - wspomina duchowny - Ukrainkę do chrztu. W pewnym momencie zapytała, czy musi teraz zmieniać narodowość, czy musi uważać się za Polkę. Takie utożsamianie bardzo ogranicza możliwość apostolskiego oddziaływania. Katolicyzm przestaje być uniwersalną doktryną, a staje się elementem wzmacniającym poczucie więzi narodowej" ${ }^{\prime 59}$.

Ten sam numer tygodnika informuje o zakończonych sukcesem staraniach wiernych o odzyskanie kościoła w Drohobyczu. 22 grudnia ubiegłego roku odbyło się uroczyste przejęcie świątyni fundowanej przez samego króla Jagiełłę, a która po wojnie światowej zamieniona została na Muzeum Religii i Sztuki. Ponownego poświęcenia kościoła dokonał biskup Stefan Moskwa, któremu asystowali duchowni z pobliskich parafii, w tym ks. W. Kiernicki oraz, jak zwykle przy takich okazjach, liczne grono wiernych. Jednocześnie autor notatki informuje czytelników o tym, iż w najbliższym czasie planowane są otwarcia kolejnych kościołów ${ }^{60}$.

W „TP” z 25 lutego tego roku opublikowana została bardzo obszerna relacja Tadeusza Fredro-Bonieckiego z wyjazdu do krajów ZSRR. Autor stwierdza, że podczas podróży miał możliwość przebywania wśród ludzi tworzących wspólnoty katolickie. Pisze też o ponaddwuletnim już staraniu Polaków z Winnicy o odzyskanie jednego z miejscowych kościołów (w jednym z nich ma swą siedzibę filharmonia, w drugim obwodowe archiwum, trzeci pełni funkcję sali wykładowej). Okazuje się, że pierwsza złożona przez nich petycja opatrzona została podpisami

\footnotetext{
${ }^{58}$ P. KOZACKI, Zeschta ziemia.

${ }^{59}$ Tamże.

${ }^{60}$ Kronika Religijna, Otwarcie kościoła katolickiego w Drohobyczu, „,Tygodnik Powszechny” 4 lutego 1990, nr 5 (2119).
} 
aż 1562 osób, niestety nie uzyskano pozytywnej odpowiedzi. Wobec tego od maja do sierpnia ubiegłego roku dwudziestu ośmiu przedstawicieli parafian prowadziło protestacyjną głodówkę na Bulwarze Smoleńskim w Moskwie. Dodatkowo po każdej niedzielnej mszy św. sprawowanej w małej kapliczce, wierni gromadzą się przed jednym z zamkniętych kościołów w centrum miasta i tam wspólnie się modlą. Kapliczka ta została wybudowana w 1982 r., na miejscu chaty na obrzeżach miasta, wbrew stanowisku lokalnych władz. Twarda postawa miejscowych katolików zapobiegła jej zniszczeniu, mimo iż kilkukrotnie podejmowano takie próby ${ }^{61}$.

O kwestiach związanych z kościołem w Winnicy autor artykułu rozmawiał między innymi z Tymofiejem Motrenko, przedstawicielem Rady ds. Religii przy Radzie Ministrów USRR dla obwodu winnickiego. Zapewnił on, iż brak zgody na oddanie kościoła nie wynika ze złej woli władz, a jest jedynie konsekwencją wcześniejszych decyzji. Wspomniane budynki zostały bowiem przeznaczone na potrzeby miasta i służą jego mieszkańcom. Zdaniem Motrenki najłatwiej byłoby przystosować do funkcji sakralnych budynek archiwum, ale miasto nie dysponuje środkami na budowę nowego gmachu. Dodatkowo obawia się reakcji w „,większości ateistycznej” społeczności miejskiej. T. Fredro-Boniecki zwrócił uwagę na fakt, że jego rozmówca wyraźnie utożsamiał katolicyzm z Polakami, a określenie „Polak” w państwie sowieckim nadal jest synonimem niepożądanej „postawy obywatelskiej”, ${ }^{2}$.

„TP” z 25 marca w dziale „Kronika Religijna” informuje o nawiązanych przed dziesięcioma dniami, oficjalnych stosunkach dyplomatycznych pomiędzy Stolicą Apostolską i ZSRR. To doniosłe wydarzenie było naturalną konsekwencją zmian zachodzących w Związku Radzieckim oraz wcześniejszych spotkań na najwyższych szczeblach państwowych ${ }^{63}$. Pierwszym oficjalnym reprezentantem Stolicy Apostolskiej w ZSRR został arcybiskup Francesco Colasuonno ${ }^{64}$.

W kolejnym numerze „TP” ukazał się fragment artykułu Przebudowa i religia $w$ ZSRR, pióra Jurija Diegtiariowa, starszego inspektora Rady ds. Wyznań przy Radzie Ministrów ZSRR. Jego zdaniem obecnie czyni się wiele, aby „przezwyciężona została sztampowość poglądów na wierzących jako na jakąś siłę obcą socjalizmowi [...]. Znalazło to przede wszystkim wyraz w sprawie rejestracji

${ }^{61}$ T. Fredro-Boniecki, Pękający mur ateizmu. Wspólnoty katolickie w ZSRR, „Tygodnik Powszechny" 25 lutego 1990, nr 8 (2122).

${ }^{62}$ Tamże.

${ }^{63} 1$ grudnia 1989 r. odbyło się spotkanie Jana Pawła II z Michaiłem Gorbaczowem w Watykanie.

${ }^{64}$ Kronika Religijna, Watykan i Moskwa nawiazaty stosunki dyplomatyczne, „Tygodnik Powszechny" 25 marca 1990, nr 12 (2126). 
wspólnot religijnych. Tak więc, jeśli w 1984 roku, według oświadczeń terenowych organów władzy Rada ds. Wyznań zarejestrowała jedynie 99 wspólnot religijnych różnych konfesji, w 1985 - 65, w 1986 - 67, 1987 - 104, to w ciągu ostatnich dwóch lat sytuacja radykalnie się zmieniła. W 1988 roku zarejestrowano już 1070 wspólnot religijnych, a w roku 1989 - 3344. Podejmowane decyzje, zezwalające wiernym na tworzenie nowych wspólnot religijnych, są wspierane przekazywaniem w ich użytkowanie budynków kultowych czy wydawaniem zezwoleń na budowę nowych [...]. W rezultacie w dyspozycji wspólnot religijnych znalazło się w 1989 roku 3100 obiektów sakralnych. Gwałtownie wzrastająca liczba działających wspólnot religijnych wymaga również dużej liczby duchownych. W związku z tym powstają nowe seminaria duchowne"65. Artykuł kończy słowami: „wierzących i niewierzących łączy wspólna historia, wspólny los, opieranie się ich działalności na ogólnoludzkich wartościach moralnych. Zdaliśmy sobie sprawę, że więcej nas łączy niż dzieli’"66. Przytoczone słowa Diegtiariowa jeszcze kilka lat wcześniej nie miałyby szans przeniknięcia przez szczelne sito państwowej cenzury. Tym bardziej nie do pomyślenia było, że takie sformułowania może wyrażać przedstawiciel władz radzieckich tej rangi. Doskonale ukazują one, jak w krótkim skądinąd czasie zmieniło się podejście do religii w państwie, które swe filary opierało na powszechnie obowiązującym ateizmie.

Święta wielkanocne stały się dla duchownych w Polsce kolejną okazją do wyjazdu na Ukrainę, aby tam na miejscu swoją obecnością wesprzeć miejscowych katolików w ich dążeniach do odbudowy struktur Kościoła katolickiego. Od Wielkiego Piątku uroczystościom przewodził biskup M. Jaworski. Szczególnym momentem była niedzielna msza rezurekcyjna, w trakcie której biskup odczytał list papieża do o. Rafała Kiernickiego, który obchodził jubileusz swojej duszpasterskiej posługi. „Dzięki silnej wierze - pisał papież - szczególnym charyzmatom i apostolskiej gorliwości umiał Ojciec, zwłaszcza w momentach najtrudniejszych dla życia religijnego i tamtejszej ludności, ożywiać i umacniać swoich wiernych, podtrzymując ich pośród doświadczeń w wierze". Kończąc krótką relację z przebiegu świąt Wielkiej Nocy w katedrze lwowskiej, autor notatki dodaje, iż na terenie archidiecezji lwowskiej jest już czynnych około 56 kościołów ${ }^{67}$.

Nie wszędzie jednak starania o odzyskanie kościołów kończyły się sukcesem. Przykładem może być Tarnopol, gdzie miejscowa społeczność katolicka, mimo iż

\footnotetext{
${ }^{65}$ Kronika Religijna, Religia w ZSRR, „Tygodnik Powszechny” 1 kwietnia 1990, nr 13 (2127).

${ }^{66}$ Tamże.

${ }^{67}$ Kronika Religijna, Wielki Tydzień $i$ Wielkanoc w katedrze lwowskiej obrządku tacińskiego, „Tygodnik Powszechny” 6 maja 1990, nr 18 (2132).
} 
spełniła wszystkie niezbędne warunki, nie otrzymała zgody na użytkowanie budynku kościelnego. Przedmiotem sporu był w tym przypadku zabytkowy kościół oo. Dominikanów, przeznaczony po wojnie na potrzeby obwodowego archiwum. Starania o jego zwrot mieszkańcy wyznania rzymskokatolickiego zainicjowali już w połowie lat osiemdziesiątych, podejmując działania mające na celu rejestrację „dwadcatki”, która miała ich reprezentować w rozmowach z władzami. Niestety, zarówno starania u władz miejscowych, jak i centralnych nie przyniosły oczekiwanego rezultatu. Na domiar złego, wbrew protestom rzymskich katolików, w sierpniu 1989 r. władze przekazały świątynię Cerkwi prawosławnej, która w tym czasie dysponowała już trzema obiektami kultu w tym mieście. We wrześniu władze cerkiewne za przyzwoleniem miejscowych władz dokonały bezmyślnego wyburzenia zabytkowego barokowego ołtarza głównego w kościele. Wkrótce świątynię przejęli grekokatolicy. Rozmowy prowadzone z Narodowym Ruchem Ukraińskim oraz Religijnym Komitetem Grekokatolików nie doprowadziły do kompromisu. Miejscowe władze podkreślały przewagę ludności wyznania grekokatolickiego nad katolikami wyznania rzymskiego. Strona polska natomiast, nie kwestionując tej przewagi stwierdzała, że nie wynika z niej konieczność zajmowania polskiego kościoła, bowiem w mieście są obiekty sakralne stanowiące własność grekokatolików. Zaproponowana przez Polaków koncepcja wspólnego użytkowania świątyni również została odrzucona. Politykę miejscowych władz autor tekstu, uczestnik tych rozmów, tłumaczy tym, iż zależy im głównie na zapewnieniu spokoju w mieście, dlatego też ulegają presji strony mającej liczebną przewagę ${ }^{68}$.

Odrodzenie Kościoła katolickiego w ZSRR nie mogło ujść uwadze polskim środowiskom naukowym, czego przykładem mogło być sympozjum pt. „Polacy w kościele katolickim w ZSRR", zorganizowane przez Katolicki Uniwersytet Lubelski $^{69}$. Jego przebieg relacjonuje notatka w „TP” z 22 lipca. Tematyka sympozjum poświęcona została sytuacji prawnej oraz polityce władz ZSRR wobec Kościoła, a także zmianom w życiu religijnym katolików od czasu rewolucji. Co ważne, w sympozjum uczestniczyli księża z Ukrainy, czyli ci, którzy nie tylko obserwowali wszystkie zmiany w ZSRR, ale przede wszystkim brali w tych zmianach czynny udział, niejednokrotnie decydując o ich kierunkach. Wśród nich był między innymi ks. L. Kamilewski ze Lwowa. W swych wystąpieniach pre-

\footnotetext{
${ }^{68}$ K.A. KLUCZNIK, Tarnopol - spór o kościót, „Tygodnik Powszechny” 24 czerwca 1990, nr 25 (2139).

${ }^{69}$ Owocem sympozjum była publikacja pt. Polacy w Kościele Katolickim w ZSRR, red. ks. E. Walewander, Lublin: RW KUL 1991.
} 
legenci przedstawili największe bolączki Kościoła katolickiego na Ukrainie. Ich zadaniem były to: brak biskupów, brak księży do pracy w odzyskiwanych przez katolików świątyniach, kłopoty z odzyskiwaniem świątyń, ogromne zapotrzebowanie na naukę religii $\mathrm{w}$ zateizowanym siłowo społeczeństwie, a także konkurencyjność odradzających się wyznań protestanckich i sekt religijnych ${ }^{70}$. Podczas dyskusji wspominano także o narastającym coraz bardziej sporze o język nabożeństw oraz nasilającej się rywalizacji pomiędzy katolikami a prawosławnymi o prawo do zamkniętych po wojnie kościołów ${ }^{71}$.

Tydzień później, tj. 29 lipca w „TP” opublikowano wiadomość o organizowanej przez Klub Inteligencji Katolickiej w Oświęcimiu pomocy dla powstających na Wołyniu parafii katolickich. Przy okazji autor tekstu zauważa, że w tej dziedzinie właśnie na Wołyniu są największe opóźnienia. Dla przykładu wskazuje miejscowość Równe, gdzie miejscowi katolicy msze św. odprawiają w zaimprowizowanej kaplicy, a księża dojeżdżają z odległych miejscowości. Wierni czynią starania mające na celu odzyskanie miejscowej świątyni, która na razie pełni funkcję sali koncertowej. W Łucku z kolei 300-osobowa wspólnota wiernych uzyskała zapewnienie władz, że od listopada będą mieli możliwość użytkowania kaplicy w katedrze św. Piotra i Pawła. Pozostałą część katedry zajmują wystawy Muzeum Ateizmu ${ }^{72}$.

W dniach od 13 do 24 lipca na Ukrainie ponownie gościł biskup M. Jaworski. W trakcie wizyty dokonał poświęcenia kolejnych świątyń odzyskanych przez tamtejszych katolików, tj. w Gródku Jagiellońskim, Połupanówce i Jezierzanach. W tych miejscowościach oraz $\mathrm{w}$ kilku innych katolickich parafiach udzielił

\footnotetext{
70 „Nasze trudności to przede wszystkim brak hierarchii. Biskupa, który reprezentowałby wobec władzy sprawy Kościoła i jednoczył rozproszonych w odległych od siebie miejscowościach kapłanów [...]. Druga nasza bolączka to brak księży do pracy w otwieranych kościołach. Ksiądz musi być stale na miejscu, poznać ludzi, stworzyć normalne życie we wspólnocie parafialnej, zająć się remontem, młodzieżą, nauczaniem, powinien prowadzić pracę misyjną, a tam gdzie trzeba polonijną, a nawet repolonizacyjną. W tej chwili nawet przy pomocy kapłanów, którzy przyjeżdżają z Polski, nie możemy należycie obsłużyć istniejących parafii, zwłaszcza że księża przyjeżdżają dorywczo na krótki czas i nie potrafią rozpoznać dobrze potrzeb naszych parafii i zaradzić im. Trzecia sprawa to odzyskanie dawnych naszych świątyń. Nie ma powodu proponować innym wyznaniom dawnych świątyń rzymskokatolickich. Jak nasza praktyka wykazała, przy otwieraniu zamkniętych kościołów, wierni i Polacy są o wiele liczniejsi na naszych terenach niż przypuszczaliśmy" (L. KAMILEwsKI, Kościót katolicki w zachodniej Ukrainie po II wojnie światowej, [w:] Polacy w kościele katolickim, s. 295-296).

${ }^{71}$ Kronika Religijna, D. PraszoŁowicz, Polacy w Kościele katolickim w ZSRR, „Tygodnik Powszechny" 22 lipca 1990, nr 29 (2143).

${ }^{72}$ Kronika Religijna, Katedra katolicka w Łucku na Wotyniu, „Tygodnik Powszechny” 29 lipca 1990, nr 30 (2144).
} 
wiernym sakramentu bierzmowania (499 osób) oraz sakramentu Pierwszej Komunii świętej (64 osoby) ${ }^{73}$.

„Tygodnik Powszechny” z 9 września informował czytelnika o kolejnych sukcesach katolików na Ukrainie na polu walki o odzyskanie zabranych im po wojnie miejsc kultu. Tym razem swój kościół odzyskali wierni z Winnicy. Ponownego poświęcenia budynku kościelnego dokonał biskup J. Dąbrowski, a w uroczystości wzięło udział liczne przedstawicielstwo duchowieństwa oraz blisko czterotysięczna rzesza wiernych. Podobne uroczystości wcześniej odbyły się w Szepetówce i Kamieńcu Podolskim. W niedzielę 29 lipca został poświęcony kościół w Fastowie ${ }^{74}$.

Niezałatwiona - jak relacjonuje autor - pozostaje natomiast sprawa zwrotu kościoła św. Aleksandra w Kijowie, zaadoptowanego na potrzeby instytucji publicznych. Pismo w tej sprawie zostało złożone zarówno u władz w Kijowie, jak i w Moskwie. Do pisma dołączono 80 arkuszy papieru, na których widnieją podpisy blisko dziesięciu tysięcy osób popierających petycję ${ }^{75}$.

O kolejnym odzyskanym przez katolików budynku kościelnym sygnalizował „TP” z 7 października, mowa tu o Odessie. Miejscowi katolicy otrzymali decyzję władz o zwrocie zabranego w 1949 r. katedralnego kościoła pw. Wniebowzięcia Najświętszej Marii Panny. Autor krótkiej notatki donosi, że decyzję o przekazaniu parafii poprzedziły długie starania katolików, którzy swoje petycje kierowali nie tylko do władz miejscowych w Odessie, ale także do Kijowa, a nawet Moskwy ${ }^{76}$.

Kolejny numer „TP” przynosi dalsze pomyślne dla katolików wieści. Tym razem nie odnoszą się one do odzyskanego kościoła, ale do zmian w prawodawstwie dotyczącym spraw religii w ZSRR. Podczas październikowej sesji obu izb Rady Najwyższej ZSRR przyjęta została ustawa $O$ wolności sumienia i organizacjach religijnych. Ustawa ma wejść w życie z chwilą publikacji, która spodziewana jest w najbliższym czasie ${ }^{77}$.

Wspominaliśmy wcześniej o oddanym katolikom kościele w Rudkach. Po blisko roku od tamtego wydarzenia kościół pw. Wniebowzięcia NMP stał się

\footnotetext{
${ }^{73}$ Kronika Religijna, Biskup Marian Jaworski na wschodnich terenach archidiecezji lwowskiej, „Tygodnik Powszechny” 12 sierpnia 1990, nr 32 (2146).

74 Kronika Religijna, MONIKA, Zwrot budynków kościelnych na Ukrainie, „Tygodnik Powszechny" 9 września 1990, nr 36 (2150).

${ }^{75}$ Tamże.

${ }^{76}$ Kronika Religijna, Zwrot kościoła w Odessie, „Tygodnik Powszechny” 7 października 1990, nr 40 (2154).

${ }^{77}$ Kronika Religijna, Ustawa „O wolności sumienia i organizacjach religijnych $w$ ZSRR”, „Tygodnik Powszechny” 14 października 1990, nr 41 (2155).
} 
miejscem kolejnego doniosłego wydarzenia. Mianowicie był to ponowny pochówek Aleksandra Fredry oraz jego rodziny, który stał się okazją do spotkania wiernych, władz kościelnych, państwowych zarówno ze strony ukraińskiej, jak i polskiej. Mszy św. przewodniczył biskup Stefan Moskwa, sufragan przemyski. Co warte dodania, uczestniczyli w niej oprócz miejscowych parafian, także liczni wierni ze Lwowa, Drohobycza, Sambora oraz z wielu innych miejscowości. W kazaniu biskup Moskwa powiedział między innymi: „Dziś znajdujemy się na ziemi, która należy do narodu ukraińskiego, ale na ziemi tej żyli i żyją nadal Polacy [...]. Wymowa dzisiejszej uroczystości jest jasna: narody chcące pielęgnować własne tradycje, własne dziedzictwo. W tej ziemi tkwią korzenie narodu ukraińskiego i narodu polskiego. Taką ziemią są Rudki. Tu znajdują się korzenie naszych narodów. Przez wiele dziesięcioleci i stuleci żyliśmy razem na tej ziemi i będziemy żyć razem"78.

Dalsza część uroczystości miała miejsce w kaplicy Fredrów, gdzie wiceminister kultury Stefan Starczewski w towarzystwie prof. Bogdana Zakrzewskiego ${ }^{79}$ oraz Tadeusza Polaka ${ }^{80}$ dokonał odsłonięcia tablicy pamiątkowej. Po okolicznościowych przemówieniach ${ }^{81}$ biskupi dokonali poświęcenia trumien ze szczątkami Fredry i jego rodziny. Uroczystości zakończyły się w godzinach wieczornych wystawioną przez Polski Teatr Ludowy we Lwowie Zemsta A. Fredry ${ }^{82}$.

18 listopada 1990 r. czytelnicy „TP” mieli możliwość zapoznania się z kolejnym wydarzeniem związanym z odrodzeniem Kościoła katolickiego na Ukrainie. W niedzielę 23 września odprawiona została pierwsza po wojnie msza św. w kaplicy kościoła katedralnego pw. św. Piotra i Pawła w Łucku. Oprócz duchownych uczestniczyło $\mathrm{w}$ niej kilkuset wiernych oraz zaproszeni goście, między innymi o. Gieorgij z soboru prawosławnego w Łucku, delegacje ukraińskiej organizacji „Ruch” i Ukraińskiej Partii Chrześcijańsko-Demokratycznej, a także przedstawiciele Towarzystwa Kultury Polskiej ze Lwowa i KIK z Oświęcimia. Starania wiernych o odzyskanie katedry rozpoczęły się już w latach siedemdziesiątych XX wieku. W tym czasie nie było jeszcze warunków do rejestracji komitetu parafialnego, co w świetle obowiązujących ówcześnie przepisów automatycznie zamykało drogę do przejęcia budynku kościelnego.

\footnotetext{
${ }^{78}$ Kronika Religijna, Uroczystości żałobne w Rudkach k. Lwowa, „Tygodnik Powszechny” 28 października 1990, $\mathrm{nr} 43$ (2157).

${ }^{79}$ BOGDAN ZAKRZEWSKI - historyk literatury, przewodniczący Komisji Fredrowskiej.

${ }^{80}$ TADEUSZ POLAK - dyrektor Funduszu Kultury Polskiej.

81 Przemówienie prof. B. Zakrzewskiego zostało przedrukowane w kolejnym numerze „TP”; B. ZAKRZEWSKI, Nad trumna Aleksandra Fredry, „Tygodnik Powszechny” 4 listopada 1990, nr 44 (2158).

${ }^{82}$ Kronika Religijna, Uroczystości żałobne w Rudkach.
} 
Dopiero przemiany lat osiemdziesiątych pozwoliły na podjęcie konkretnych kroków. W październiku 1989 r. udało się zarejestrować komitet parafialny i rozpocząć właściwe starania o odzyskanie katedry. Na razie wierni odzyskali kaplicę katedry, w której nadal czynne jest Muzeum Ateizmu. Kaplica ma być czynna codziennie w godzinach 16-18, a msze św. będą odprawiane w każdą niedzielę przez księży z pobliskich parafiii ${ }^{83}$.

W dniach 31października - 6 listopada biskup M. Jaworski odbył kolejną wizytę na terenach archidiecezji lwowskiej znajdujących się poza granicami Polski. Jak zawsze, na łamach „TP” ukazała się relacja krótko opisująca jej przebieg. W trakcie wizyty odprawił wiele nabożeństw i dokonał poświęcenia czterech nowo odzyskanych kościołów: w Kopyczyńcach, Kołomyi, Mikołajowie i Chodorowie. Ponadto biskup udzielił sakramentu bierzmowania 50 dorosłym mieszkańcom Stanisławowa. Kulminacyjnym elementem wizyty była msza św. odprawiona przez biskupa M. Jaworskiego w katedrze lwowskiej, w której uczestniczyło 23 kapłanów pracujących na tym terenie. Spotkanie po mszy św. było okazją do podzielenia się zaobserwowanymi przez księży spostrzeżeniami. Dało też możliwość dokonania oceny dotychczasowych działań podejmowanych na rzecz odrodzenia Kościoła katolickiego na Ukrainie i opracowania planu działania na przyszłość. Kapłani sprawujący posługę na terenie Ukrainy, prosili biskupa M. Jaworskiego przede wszystkim o przysłanie kolejnych księży. Ich zdaniem problem ten jest jednym $\mathrm{z}$ najistotniejszych, $\mathrm{z}$ jakimi aktualnie zmaga się tamtejsza wspólnota rzymskokatolicka ${ }^{84}$.

$\mathrm{Na}$ początku grudnia na łamach „TP” ukazał się artykuł pióra ks. Tadeusza Ślipko, niejako podsumowujący dotychczasowy proces odrodzenia życia religijnego na Ukrainie. Ks. Ślipko zauważa, iż aktualnie na terenie trzech rejonów: lwowskiego, tarnopolskiego i stanisławowskiego, funkcjonuje już 70 kościołów. Kolejnych kilkanaście przygotowanych jest do otwarcia i poświęcenia. Gdyby nieliczne trudności, jakie napotyka akcja rewindykacyjna, liczba ta byłaby zapewne znacznie większa. Co ważne, nie brak ani budynków, które nadal mogą służyć za obiekty sakralne, ani tym bardziej wiernych, którzy podjęliby trud ich odrestaurowania. Podobna sytuacja występuje na terenach między Zbruczem a Dniestrem. Głównym problemem Kościoła rzymskokatolickiego na Ukrainie pozostaje nadal niewielka liczba kapłanów. Jak podaje autor, 70 kościołów na

\footnotetext{
${ }^{83}$ Kronika Religijna, M. MALINOwsKI, Wznowienie nabożeństw w katedrze katolickiej $w$ Łucku, „Tygodnik Powszechny” 18 listopada 1990, nr 46 (2159).

${ }^{84}$ Kronika Religijna, Biskup Marian Jaworski na wschodnich terenach archidiecezji lwowskiej, „Tygodnik Powszechny” 25 listopada 1990, nr 47 (2160).
} 
zachodniej Ukrainie obsługuje jedynie trzynastu księży, z których dwóch jest w podeszłym wieku i ma poważne problemy ze zdrowiem. Doraźna pomoc ze strony Polski nie rozwiązuje niestety problemu. Kolejna trudność, z jaką przychodzi się zmagać katolikom na Ukrainie, to brak oficjalnej, zinstytucjonalizowanej reprezentacji Kościoła rzymskokatolickiego. I w tym przypadku okazyjne wizyty biskupa M. Jaworskiego i innych duchownych nie rozwiązują problemu. Sytuacja ta skutkuje między innymi brakiem organu, który z racji swej hierarchii mógłby skutecznie reprezentować Kościół w stosunkach z władzami państwowymi. Dlatego też kapłani skazani są na indywidualne kontakty z władzami, co siłą rzeczy osłabia ich pozycję w prowadzonych rozmowach. Niemniej jednak ostatnimi czasy „Kościół katolicki dźwignął się do życia jak Feniks z popiołów”85.

ROK 1991

Wspominaliśmy wcześniej o udostępnionej katolikom w Łucku kaplicy w katedrze pw. św. Piotra i Pawła. Na początku 1991 r. na łamach „TP” ukazał się tekst o pierwszej Pasterce obchodzonej w tej świątyni. Zaproszenie na mszę św. otrzymał między innymi ks. Jan Zając, a także członkowie KIK z Oświęcimia. W noc Bożego Narodzenia w katedrze łuckiej zgromadziło się kilkuset wiernych. Niewielka kaplica nie była w stanie wszystkich pomieścić, dlatego też część z nich wypełniła działające tam nadal Muzeum Ateizmu. Na Pasterce obecna była także delegacja miejscowej Cerkwi ukraińskiej. Warto podkreślić, że świąteczny nastrój udzielił się również pracownikom Muzeum Ateizmu, którzy z własnej inicjatywy zorganizowali małą wystawę o Bożym Narodzeniu. W trzech gablotach umieszczono reprodukcje obrazów, pocztówki i kalendarze związane z tematyką świąteczną. Kolędowanie trwało bardzo długo, był to swoisty paradoks - pieśni religijne głośno pobrzmiewające w budynku, który miał z założenia być symbolem powszechnego ateizmu ${ }^{86}$.

Ostatni styczniowy numer „TP” przynosił informację, której jeszcze parę lat wcześniej nie dałby wiary nawet największy optymista. Oto 16 stycznia $1991 \mathrm{r}$. Radio Watykańskie ogłosiło następujące nominacje biskupie dokonane przez Jana

${ }^{85}$ T. ŚLIPKO, Nadzieja Kościoła. Katolicy obrzadku rzymskiego na Ukrainie, „Tygodnik Powszechny" 16 grudnia 1990, nr 50 (2164).

${ }^{86}$ Kronika Religijna, M. Malinowski, Pasterka w Muzeum Ateizmu, „Tygodnik Powszechny” 20 stycznia 1991, nr 3 (2167). 
Pawła II: biskup Marian Jaworski został mianowany arcybiskupem - metropolita lwowskim obrządku łacińskiego, ks. infułat Rafał Kiernicki oraz ks. Marcjan Trofimiak zostali biskupami pomocniczymi arcybiskupa Jaworskiego. Ks. Jan Olszański został mianowany biskupem ordynariuszem diecezji kamienieckiej, natomiast ks. Jan Purwiński biskupem ordynariuszem diecezji żytomierskiej ${ }^{87}$.

Wszystkie ogłoszone nominacje, także biskupów obrządku bizantyjsko-ukraińskiego, stanowiły doniosłe wydarzenie w dziejach Kościoła katolickiego w Europie Wschodniej. Metropolita lwowski został mianowany po 28 latach od śmierci swojego poprzednika arcybiskupa Eugeniusza Baziaka ${ }^{88}$. Nominacje biskupie oraz stała obecność metropolity daje też szansę na wznowienie działalności lwowskiego Seminarium Duchownego ${ }^{89}$. Tematyka nominacji biskupich znalazła swoją kontynuację także w „TP” z 10 lutego 1991 r., kiedy to w dziale na łamach pisma zamieszczone zostały krótkie biogramy nowo mianowanych biskupów $^{90}$.

W „TP” z 24 lutego opublikowany został wywiad z biskupem M. Trofimiakiem, przeprowadzony przez Mieczysława Malinowskiego i ks. J. Zająca. W wywiadzie tym poruszono wiele kwestii związanych z odradzaniem się życia religijnego oraz funkcjonowaniem wspólnot rzymskokatolickich na Ukrainie. „Nigdy - mówił biskup - nie oddano świątyni bez starań ludzi świeckich. Dużo zależy od miejscowych władz. Na przykład w Czortkowie na początku szło nam bardzo trudno [...]. Teraz władze czortkowskie odnoszą się do nas zupełnie inaczej, jeśli chodzi o zwrot kościołów. W tym powiecie nie ma już żadnych trudności. Powiemy, że chcemy gdzieś odprawiać, odpowiadają: proszę bardzo, dajcie pismo, zbierajcie »dwudziestkę« i odprawiajcie nabożeństwo, nie ma przeszkód. Gorzej wygląda sprawa kościoła w Tarnopolu. Niestety kościół przekazano najpierw prawosławnym, potem grekokatolikom, nie nam. Jest to jedyna ocalała świątynia w Tarnopolu. Parafia nasza jest zarejestrowana, istnieje oficjalnie, lecz nie mamy gdzie odprawiać". Biskup podkreślił także pilną potrzebę kształcenia duchownych na terenie Ukrainy. W tym roku udało się wysłać sześciu kleryków do seminarium w Lublinie i Przemyślu. Niestety, w jego ocenie potrzeby są dużo większe ${ }^{91}$.

\footnotetext{
87 A. BARDECKI, Powrót kościoła hierarchicznego na Ukrainę, „Tygodnik Powszechny” 27 stycznia 1991, nr 4 (2168).

${ }^{88}$ Ks. arcybiskup Eugeniusz Baziak zmarł 15 czerwca 1962 r.

${ }^{89}$ A. BARDECKI, Powrót kościoła hierarchicznego.

${ }^{90}$ Kronika Religijna, Nowo mianowani biskupi obrzadku tacińskiego we Lwowie, „Tygodnik Powszechny" 10 lutego 1991, nr 6 (2170).

${ }^{91}$ Kaptan z kresów. Z księdzem Markijanem Trofimiakiem rozmawiają Mieczystaw Malinowski $i$ ks. Jan Zając, „Tygodnik Powszechny” 24 lutego 1991, nr 8 (2172). Na marginesie redaktor zau-
} 
W związku z dokonanymi przez papieża nominacjami 2 marca odbyła się kolejna uroczystość, która ze względu na swą rangę przejdzie do historii. Tego dnia w katedrze lwowskiej dokonano konsekracji trzech biskupów rzymskokatolickich. Na uroczystości zgromadziło się około 8 tysięcy wiernych, którzy przybyli niemal z całej Ukrainy, obecni byli także goście z Polski. Wymiar tego wydarzenia podkreśla chociażby fakt, iż w samej koncelebrze brało udział prawie 150 duchownych ${ }^{92}$.

W tym samym tygodniku, w którym zamieszczono relację $\mathrm{z}$ powyższej uroczystości, przedrukowano także list skierowany przez papieża Jana Pawła II do arcybiskupa lwowskiego. Oprócz gratulacji i błogosławieństwa na nową drogę, papież pisał o historycznym znaczeniu powrotu „Kościoła do Miasta, z którym był od tylu stuleci związany"93.

Po całej serii pozytywnych informacji docierających do Polski za pośrednictwem „TP”, przyszła wiadomość o uchwale Lwowskiej Rady Deputowanych, żądającej przeniesienia zaplanowanego na 6 kwietnia ingresu arcybiskupa M. Jaworskiego na termin późniejszy ${ }^{94}$. Żądanie to władze tłumaczą wzrostem napięć społecznych „oraz złożoną sytuacją religijną”. Przyjazd do Lwowa metropolity obrządku łacińskiego - w ocenie władz - może prowadzić do zaostrzenia sytuacji politycznej w mieście oraz „niekontrolowanych ekscesów”. Zdaniem autora artykułu, Jerzego Turowicza, stanowisko władz lwowskich wynika między innymi z toczącego się w tym czasie konfliktu o katedrę w Przemyślu. Nie był to oczywiście jedyny powód, który skłonił władze miejskie do podjęcia takich kroków. Od dłuższego czasu dało się zauważyć, z jaką niechęcią niektóre środowiska ukraińskie patrzą na odradzającą się strukturę Kościoła katolickiego obrządku łacińskiego na Ukrainie. W grę wchodziły nie tylko lokalne konflikty o budynki sakralne, coraz częściej Kościół katolicki oskarżano o polonizację ziem ukraińskich, a wobec osób, które identyfikowały się z Polską, wyrażano negatywne opinie. Dla przykładu można tu wskazać manifestację, jaka na początku kwietnia przeszła ulicami Lwowa. Demonstranci protestowali przeciw-

\footnotetext{
waża, że wszelkie dostępne źródła podają imię biskupa - Markijan, sam biskup przedstawia się natomiast jako Marcjan.

${ }_{92}$ M. BuczeK, Historyczna chwila. Święcenia biskupie w katedrze lwowskiej i Żytomierzu, „Tygodnik Powszechny” 24 marca 1991, nr 12 (2176).

${ }_{93}$ Historyczna chwila. Papież do arcybiskupa lwowskiego, „Tygodnik Powszechny” 24 marca 1991, nr 12 (2176).

${ }^{94}$ Pierwotnie ingres arcybiskupa M. Jaworskiego zaplanowano na początek marca. Jednakże na wniosek władz lwowskich termin ten przesunięto na kolejny miesiąc.
} 
ko reaktywowaniu na Ukrainie kościoła obrządku łacińskiego. Decyzję podjętą przez Stolicę Apostolską traktowano ,jako spisek Rzymu i Moskwy, aby wzmocnić na Ukrainie polski szowinizm". Manifestacja ta niewątpliwie również wpłynęła na stanowisko lwowskich władz. Strona ukraińska podnosiła też zarzut, iż mianowanie przez papieża trzech biskupów ordynariuszy i dwóch biskupów pomocniczych dla „garstki Polaków” kontrastuje z nominacją tylko jednego biskupa dla 300 tysięcy katolickich Ukraińców w Polsce. Dalej, zdaniem niektórych środowisk ukraińskich, liczba zwróconych katolikom obrządku łacińskiego (czytaj: Polakom) kościołów nijak się ma do ich faktycznej liczebności. Wynika ona jedynie z lęku władz ,przed protestami polskimi" ${ }^{\prime 95}$.

Mimo piętrzących się trudności, z Ukrainy nadal docierały wieści o kolejnych odzyskanych tam przez katolików parafii. W „TP” z 21 lipca ukazała się krótka notatka o przekazaniu parafianom osiemnastowiecznej świątyni w Łopatynie, zmienionej po wojnie na magazyn. Komitet kościelny powstał tam w marcu 1990 r., uzyskane przez wiernych środki pozwoliły na przeprowadzenie niezbędnych prac remontowych oraz przygotowanie kościoła do ponownego poświęcenia. Uroczystość ta odbyła się w niedzielę 16 czerwca, przewodniczył jej biskup R. Kiernicki. Towarzyszyło mu kilku księży oraz ogromna rzesza wiernych, nie zabrakło także rodaków z Polski. Wśród gości z kraju przeważały osoby, które przed wojną należały do parafii w Łopatynie, a następnie w ramach akcji repatriacyjnej zostały przesiedlone do Polski, głównie do miejscowości Wójcice ${ }^{96}$.

Zwracane przez władze kościoły na Ukrainie zazwyczaj znajdowały się w stanie ruiny. Przeprowadzane przez parafian wstępne prace remontowo-porządkowe nie były w stanie przywrócić kościelnych budynków do stanu, w jakim znajdowały się przed wojną. Zniszczenia, jakim uległy w okresie ich zamknięcia, wymagały dużych nakładów finansowych i pomocy ze strony specjalistów. Informacje te także docierały do czytelników „TP”. Dla przykładu można wskazać numer 31 tygodnika z 1991 r., na łamach którego zamieszczony został list o. Stanisława Szczygłosa. Ten proboszcz parafii w Drohobyczu, zwróconej wiernym pod koniec 1989 r., podkreśla, że natychmiastowej restauracji potrzebują między innymi zabytkowe freski, renesansowy nagrobek oraz marmurowy portal z XV wieku. Wszystkie te prace wymagają opłacenia spe-

\footnotetext{
${ }^{95}$ S. MusiaŁ, Podziały religijne na Ukrainie. Chrześcijaństwo żywe, „Tygodnik Powszechny” 5 maja 1991, nr 18 (2182).

${ }^{96}$ T. KUKIZ, Konsekracja Kościoła katedralnego w Eopatynie, „Tygodnik Powszechny” 21 lipca 1991, nr 29 (2193).
} 
cjalistów z dziedziny konserwacji zabytków oraz zapewnienia im odpowiednich materiałów. Wobec tego, iż kosztów tych nie są w stanie ponieść miejscowi parafianie, proboszcz prosi o wsparcie finansowe rodaków ${ }^{97}$.

Rozpoczęte dwa lata wcześniej starania wiernych w Łucku o zwrot miejscowej katedry, przyniosły wreszcie szczęśliwe zakończenie. Pisaliśmy już o udostępnionej parafianom kaplicy kościelnej, jednakże dopiero 26 czerwca budynek katedry oficjalnie powrócił do swych prawowitych właścicieli. Świątynia znajduje się w dość dobrym stanie, jedynie ołtarz został rozebrany, a w jego miejscu stanęła kopuła $\mathrm{z}$ żelaza i betonu przedstawiająca kosmos. Funkcję proboszcza objął ks. L. Kamilewski, który przybył ze Lwowa ${ }^{98}$.

W pierwszym listopadowym wydaniu „TP” zamieszczona została notatka o kolejnej wizycie duszpasterskiej na terenie archidiecezji lwowskiej metropolity lwowskiego arcybiskupa M. Jaworskiego, która to miała miejsce w pierwszej połowie października $1991 \mathrm{r}$. Ponadto autor tekstu informuje czytelnika o udzieleniu w katedrze lwowskiej święceń kapłańskich dwóm diakonom. Kolejnych dziesięciu kleryków z Ukrainy kształci się w Seminarium Duchownym w Lublinie ${ }^{99}$.

\section{ZAKOŃCZENIE}

Publikowane na łamach „Tygodnika Powszechnego” artykuły dawały czytelnikowi możliwość w miarę dobrego rozeznania w kwestiach związanych z odradzającym się za wschodnią granicą życiem religijnym, choć poszczególne informacje różniły się pod względem swojej szczegółowości.

W 1988 r. zabrakło informacji o zwracanych wiernym kościołach, choć wiemy, że takie przypadki miały miejsce. Niemniej jednak artykuły w oczywisty sposób obrazowały zmianę stosunku władz radzieckich do Kościoła katolickiego. Pierwsze oficjalne kontakty władz radzieckich ze Stolicą Apostolską oraz przedstawicielami Kościoła katolickiego pozwoliły postawić na porządku dziennym problemy, które dotychczas w kręgach najwyższych czynników państwowych oficjalnie nie istniały. Kontakty te szybko zaczęły przynosić wymierne

\footnotetext{
${ }^{97}$ K. SzczygŁos, Kościót w Drohobyczu, [Do Redakcji], „Tygodnik Powszechny” 4 sierpnia 1991, nr 31 (2195).

${ }^{98}$ Kronika Religijna, M. MALINOwsKI, Katedra $w$ Łucku powróciła do wiernych, „Tygodnik Powszechny" 1 września 1991, nr 35 (2199).

${ }^{99}$ Kronika Religijna, Wizyta duszpasterska metropolity lwowskiego na Ukrainie, „Tygodnik Powszechny" 3 listopada 1991, nr 44 (2208).
} 
efekty, między innymi nieliczne na razie przypadki pozwoleń na nauczanie religii w szkołach, ale przede wszystkim w postaci zwrotu parafii wiernym, choć prawdziwie obfitym w te wydarzenia miał być dopiero rok przyszły. Niewątpliwie rok 1988 był przełomowy, zepchnięty do podziemia Kościół katolicki, na razie nieśmiało i $\mathrm{z}$ pewnymi obawami dawał znać o swoim istnieniu, ukazując jednocześnie kompletną klęskę władz radzieckich na polu sowietyzacji i ateizacji społeczeństwa, które - jeśli chodzi o zachodnią Ukrainę - przez blisko pięć dziesięcioleci nie potrafiły wykorzenić katolicyzmu. Wiara ta, ukryta głównie w zaciszu czterech ścian katolickich domostw przetrwała, a wraz z nią przetrwało też przywiązanie do polskości.

W 1989 r. praktycznie w każdym numerze tygodnika zamieszczono informacje o odradzającym się powoli życiu religijnym. Część z nich odnosiła się do szeroko rozumianej polityki państwowej, część natomiast przedstawiała kolejne świątynie, które dzięki zaangażowaniu miejscowych wspólnot rzymskokatolickich powracały do tych, którym po wojnie je odebrano. Na łamach „TP” pisano też o pierwszych trudnościach, z jakimi przyszło zmierzyć się lokalnym wspólnotom katolickim. Chodzi tu przede wszystkim o brak kapłanów, których niewielka liczba nie była w stanie zaspokoić potrzeb odradzających się licznie parafii, oraz stan zwracanych wiernym budynków kościelnych. Powybijane okna, przeciekające dachy czy zawilgocone ściany, zniszczone i rozgrabione elementy wystroju wnętrz - to określenia, które charakteryzowały większość z nich. Skromne środki, jakimi dysponowali miejscowi katolicy, nie wystarczały zazwyczaj na pokrycie podstawowych potrzeb dnia codziennego, nie mówiąc już o partycypowaniu w kosztownych remontach świątyń.

Rok 1990 przynosił kolejne informacje o zwracanych parafianom kościołach, niemniej jednak coraz częściej do czytelnika docierały informacje o rodzących się na tym tle sporach z grekokatolikami. Przykładem może tu być konflikt o budynek kościelny oo. Dominikanów w Tarnopolu, który mimo wieloletnich starań katolików polskiego pochodzenia nie został im zwrócony. Nadal odczuwalny był brak odpowiedniej liczby kapłanów, dodatkowo zwrócono też uwagę na pilną potrzebę odbudowy struktur Kościoła katolickiego na Ukrainie.

Wyraźnie mniej obfity w informacje o zwrotach kościołów był już natomiast rok 1991. Najważniejszym wydarzeniem były niewątpliwie nominacje biskupie, przywracające między innymi po 28 latach funkcję metropolity lwowskiego obrządku łacińskiego. Niestety, na te pozytywne wieści cieniem kładły się późniejsze próby niedopuszczenia do ingresu arcybiskupa M. Jaworskiego w kate- 
drze lwowskiej oraz towarzyszące im manifestacje, na których skandowano hasła o wyraźnie antypolskim wydźwięku.

Podsumowując analizę publikacji zamieszczonych na łamach „TP” w latach 1988-1991 i dotyczących odrodzenia religijnego za naszą wschodnią granicą, możemy wyrazić opinię, iż zamieszczone tam artykuły przekazywały czytelnikowi w miarę aktualny i pełny obraz zmian, jakie w tym czasie zachodziły na terytorium USRR. Pierwsze oznaki pozytywnych przemian miały miejsce już w 1988 r., co uwidoczniło się także na łamach pisma. Kolejne dwa lata, czyli okres obfitujący w najwięcej wydarzeń z tym związanych, również przyniósł sporo artykułów na ten temat. Naturalnie mniej relacji zawierały tygodniki wydane w kolejnym roku, wtedy bowiem proces zwrotu kościołów uległ wyraźnemu spowolnieniu. Można oczywiście powiedzieć, że - po pierwsze - relacji tych mogło być więcej, po drugie zaś, iż mogły one być bardziej szczegółowe. Niemniej należy pamiętać, że tematyka podejmowana na łamach „TP” dotyczyła i dotyczy nadal bardzo szerokiego kręgu spraw, od polityki zaczynając na kulturze kończąc. Interesująca nas kwestia, choć niewątpliwie istotna i ciekawa, dotyczyła tylko wąskiego wycinka ówczesnej rzeczywistości. Rzeczywistości, która dla wszystkich państw komunistycznych Europy Środkowo-Wschodniej była okresem przełomowym, bogatym w wydarzenia, które zmieniły bieg historii.

\section{BIBLIOGRAFIA}

\section{Prasa}

„Tygodnik Powszechny”

ROK 1988 - 24.01.1988, nr 4 (2013); 15.05.1988, nr 20 (2029); 26.06.1988, nr 26 (2035); 14.08.1988, nr 33 (2042); 23.10.1988, nr 43 (2052); 30.10.1988, nr 44 (2053); 20.11.1988, nr 47 (2056); 04.12.1988, nr 49 (2058); 11.12.1988, nr 50 (2059).

ROK 1989 - 08.01.1989, nr 2 (2063); 15.01.1989, nr 3 (2064); 22.01.1989, nr 4 (2065); 29.01.1989, nr 5 (2066); 19.02.1989, nr 8 (2069); 02.04.1989, nr 14 (2075); 09.04.1989, nr 15 (2076); 21.05.1989, nr 21 (2082); 18.06.1989, nr 25 (2086); 06.08.1989, nr 32 (2093); 13.08.1989, nr 33 (2094); 29.10.1989, nr 44 (2105); 05.11.1989, nr 45 (2106); 19.11.1989, nr 47 (2108); 03.12.1989, nr 49 (2110).

ROK 1990 - 14.01.1990, nr 2 (2116); 21.01.1990, nr 3 (2117); 04.02.1990, nr 5 (2119); 25.02.1990, nr 8 (2122); 25.03.1990, nr 12 (2126); 01.04.1990, nr 13 (2127); 06.05.1990, nr 18 (2132); 24.06.1990, nr 25 (2139); 22.07.1990, nr 29 (2143); 29.07.1990, nr 30 (2144); 12.08.1990, nr 32 (2146); 09.09.1990, nr 36 (2150); 07.10.1990, nr 40 (2154); 14.10.1990, nr 41 (2155); 28.10.1990, nr 43 (2157); 
04.11.1990, nr 44 (2158); 18.11.1990, nr 46 (2159); 25.11.1990, nr 47 (2160); 16.12.1990, nr 50 (2164).

ROK 1991 - 20.01.1991, nr 3 (2167); 27.01.1991, nr 4 (2168); 10.02.1991, nr 6 (2170); 24.02.1991, nr 8 (2172); 24.03.1991, nr 12 (2176); 05.05.1991, nr 18 (2182); 21.07.1991, nr 29 (2193); 04.08.1991, nr 31 (2195); 01.09.1991, nr 35 (2199); 03.11.1991, nr 44 (2208).

\section{Opracowania}

DZWONKOWSKI R., Leksykon duchowieństwa polskiego represjonowanego w ZSRR 1939-1988, Lublin: TN KUL 2003.

Dzwonkowski R., Polacy w Kościele katolickim na wschodzie (1939-2011), Toruń: Wydawnictwo Adam Marszałek 2011.

Dzwonkowski R., Polacy w Kościele katolickim w krajach byłego ZSRR, [w:] Polskie odrodzenie na Wschodzie. Materiały z międzynarodowej konferencji naukowej nt. „Polacy w procesie transformacji systemowej i ustrojowej krajów byłego Związku Radzieckiego" zorganizowanej w Siedlcach 16 listopada 1998 roku, red. A Bobryk, J. Jaroń, Siedlce: Wydawnictwo Akademii Podlaskiej 1999.

DzWONKOwsKI R., Religia i Kościół katolicki w ZSRR oraz w krajach i na ziemiach okupowanych 1917-1991; kronika, Lublin: TN KUL 2010.

HLEbowicz A., Katolicyzm w państwie sowieckim 1944-1992. Kościół odrodzony, Gdańsk: Wydawnictwo Stella Maris 1993.

JONIEC Ł., Powojenna sytuacja Kościoła katolickiego na terenach byłego województwa lwowskiego na przykładzie losów kolegiaty żółkiewskiej, ,Studia Gdańskie” 35 (2014).

JONIEC Ł., Z działalności Towarzystwa Kultury Polskiej Ziemi Lwowskiej oddział w Żółkwi w latach 2003-2011, „HISTORIC@.” Czasopismo naukowe doktorantów Uniwersytetu Rzeszowskiego 2016, nr 18.

KIERNICKI R.W., Duszpasterz mimo woli, [w:] Wytrwać i przetrwać jak Bóg daje. Świadkowie Kościoła rzymskokatolickiego na Ukrainie Sowieckiej 1917-1991, red. J. Wołczański, Kraków: Wydawnictwo UNUM 2010.

KRĘTOSZ J., Katedra obrządku łacińskiego we Lwowie i jej proboszcz o. Rafał Kiernicki OFM Conv w latach 1948-1991, Katowice: UŚ 2003.

OsADCZY W., Kościoła łacińskiego na Ukrainie dole i niedole. Doświadczenie, dzień dzisiejszy, problemy i perspektywy, [w:] Kościół katolicki na Wschodzie w warunkach totalitaryzmu i posttotalitaryzmu, red. A. Gil, W. Bobryk, Siedlce-Lublin: Wydawnictwo Akademii Podlaskiej 2010.

OSADCZY W., Władyka Markijan. O historii i dniu dzisiejszym Kościoła katolickiego na Ukrainie z księdzem biskupem Marcjanem Trofimiakiem rozmawia Włodzimierz Osadczy, Lublin-Łuck: Wydawnictwo KUL 2009.

Polacy w Kościele Katolickim w ZSRR, red. ks. E. Walewander, Lublin: RW KUL 1991.

RENIK K., Podpolnicy. Rozmowy z ludźmi Kościoła na Litwie, Łotwie, Białorusi i Ukrainie 1990-1991, Warszawa: Oficyna Przeglądu Powszechnego 1991. 
SZYMAŃSKI J., Dwadcatki - organy wykonawcze organizacji religijnych w sowieckim systemie represji (Obwód Winnicki na Podolu, 1944-1964), „Roczniki Teologiczne” 50(2003), z. 4, s. 171-195.

SZYMAŃSKI J., Kapłan katolicki jako inicjator i koordynator środowisk polskich na Ukrainie, [w:] Funkcje i zadania elit w środowiskach polonijnych, red. J. Knopek, Toruń: Wydawnictwo Adam Marszałek 2006.

TROFIMIAK M., Świadectwo archidiecezji lwowskiej obrządku łacińskiego (Ukraina), [w:] Świadectwo Kościoła katolickiego w systemie totalitarnym Europy ŚrodkowoWschodniej. Księga Kongresu Teologicznego Europy Środkowo-Wschodniej KUL, 11-15 sierpnia 1991, red. J. Nagórny [i in.], Lublin: RW KUL 1994.

\author{
ODRODZENIE ŻYCIA RELIGIJNEGO W UKRAIŃSKIEJ \\ SOCJALISTYCZNEJ REPUBLICE RADZIECKIEJ \\ W ŚWIETLE ARTYKUŁÓW ZAMIESZCZONYCH NA ŁAMACH \\ „TYGODNIKA POWSZECHNEGO” W LATACH 1988-1991
}

\title{
Streszczenie
}

Schyłek lat osiemdziesiątych i początek lat dziewięćdziesiątych XX wieku dla większości państw Europy Środkowo-Wschodniej był okresem przełomowym. Wydarzenia zapoczątkowane reformami M. Gorbaczowa nie ominęły także terytorium naszego wschodniego sąsiada - Ukrainy. Pozwoliły one państwu ukraińskiemu na wydostanie się spod hegemonii Moskwy, a następnie umożliwiły budowanie własnej podmiotowości na arenie międzynarodowej oraz ustroju opartego - przynajmniej w teorii - o zasady obowiązujące w demokratycznym państwie prawa. Reformy te zmieniły zasadniczo także pozycję funkcjonujących tam wspólnot religijnych, w tym Kościoła katolickiego. Zerwanie z obowiązującą od dziesięcioleci polityką ateizacji i sowietyzacji społeczeństwa zapoczątkowało spontaniczne odrodzenie religijne, co w konsekwencji doprowadziło do odbudowania struktur Kościoła katolickiego. Wieści o odradzającym się za wschodnią granicą życiu religijnym docierały do Polski między innymi. za sprawą artykułów publikowanych na łamach prasy, w tym „Tygodnika Powszechnego”. Analiza tekstów zamieszczonych na jego kartach w latach 1988-1991 pozwala na stwierdzenie, iż przekazywały one w miarę aktualny oraz pełny obraz zmian, jakie w tym czasie zachodziły na terytorium Ukrainy. Czytelnik informowany był zarówno o reformach obejmujących swym zasięgiem cały kraj, w tym obrazujących zmianę podejścia władz państwowych do kwestii związanych z religią, jak też o sukcesach lokalnych wspólnot katolickich, które dzięki nieprawdopodobnemu wręcz zaangażowaniu potrafiły, pomimo skromnych zazwyczaj możliwości, odzyskać szereg budynków kościelnych, a w dalszej kolejności odbudować struktury poszczególnych parafii. Niestety, pozytywny obraz zachodzących zmian psuły nasilające się od początku lat dziewięćdziesiątych konflikty z ukraińskimi władzami państwowymi, a co gorsza - także z przedstawicielami innych wyznań. Konflikty te, dotyczące głównie kwestii związanych ze zwrotem budynków sakralnych, również zna- 
lazły swe odzwierciedlenie na kartach „Tygodnika Powszechnego”. Dzięki temu czytelnik na bieżąco mógł śledzić wydarzenia związane z odrodzeniem życia religijnego na Ukrainie.

Słowa kluczowe: archidiecezja lwowska; ateizacja; katolicyzm; Kościół katolicki; odrodzenie religijne; parafia katolicka; Stolica Apostolska; „Tygodnik Powszechny”; Ukraina; Związek Socjalistycznych Republik Radzieckich.

\section{THE REBIRTH OF RELIGIOUS LIFE IN THE SOVIET SOCIALIST REPUBLIC \\ OF UKRAINE IN THE LIGHT OF THE ARTICLES PUBLISHED IN „TYGODNIK POWSZECHNY” IN THE YEARS 1988-1991}

\section{S u m mary}

The period between late 1980s and early 1990s was a turning point for the majority of Central and Eastern European countries. The events initiated by Gorbachev's reforms affected Ukraine. They allowed the Ukrainian state to leave the Moscow's area of influence, and build its own subjectivity on the international stage and a system based, at least theoretically, on the democratic rule of law. These reforms fundamentally changed the position of the religious communities functioning there, including the Catholic Church. Breaking with the policy of atheization and the sovietization of society that had been in force for decades has initiated a spontaneous religious revival, which in turn led to the rebuilding of the structures of the Catholic Church. The news of the reviving religious life coming from across the Eastern border was heard in Poland, among others due to press articles, including the articles published in "Tygodnik Powszechny." An analysis of the texts published in "Tygodnik Powszechny" in 1988-1991 shows that they provided a complete and up-to-date description of the changes that occurred in Ukraine at that time. The reader was informed about reforms across the whole country, including the change in the attitude of state authorities to matters related to religion, as well as about the successes of local Catholic communities, which, due to their great commitment, managed to regain a number of church buildings and rebuild the structures of individual parishes, despite limitations in their functionality. Unfortunately, the positive picture of the ongoing changes was tarnished by the conflicts with the Ukrainian state authorities, which had been growing since the beginning of the 1990s, and, what was worse, with the representatives of other religions. These conflicts, mainly concerning issues related to the return of religious buildings, were reflected in the articles published in Tygodnik Powszechny. Due to this, the reader could follow events related to the revival of religious life in Ukraine on an ongoing basis.

Key words: Archdiocese of Lviv; Atheisation; Catholicism; The Catholic Church; revival; Catholic parish; Holy See; "Tygodnik Powszechny”; Ukraine; Soviet Union. 